\title{
Türkiye'deki Yabancı Sermayeli Bankaların CAMELS Analizi ile Performanslarının Ölçümü
}

\author{
Ali USLU*
}

\section{$\ddot{O Z Z E T}$}

Çalı̧̧mada Türkiye'deki yabancı sermayeli bankaların performanslarının karşılaş̧tırılması amaçlanmıştır. Türkiye'deki 12 yabancı sermayeli banka CAMELS derecelendirme sistemi ile analiz edilmiştir. Analize dâhil edilen bankaları 2010-2016 yılları performansları 23 finansal oranla ölçülmüştür.

Analiz bulguları, 2010 yılı esas alındığında 2016 yılında yabancı bankaların \% 50'sinde performans düşüsü olduğunu göstermistir. Genel olarak 2014 yılından sonra; banka kârlılığının, yönetim kalitesinin ve sermaye yeterliliklerinin düştüğü gözlemlenmiştir. Likidite yeterliliği ve aktif kalitesinin arttı̆̆l, piyasa riskine duyarlılığın ise toparlanarak küçük bir artış gösterdiği ortaya çıkarılmıştır. Sermaye yeterliliğinde fazla bir düşüş olmasa da bazı bankaların sektörün gerisinde kaldiğl tespit edilmiştir.

Anahtar Kelimeler: CAMELS, Bankalar, Performans Analizi.

JEL Sınıflandırması: C60, G21, P17. Analysis

\section{A Performance Measurement of Foreign Capital Banks in Turkey by CAMELS}

\section{ABSTRACT}

In this study, aimed that compare of the performance of foreign capital banks in Turkey. 12 foreign capital banks in Turkey were analysis by CAMELS rating system. The performance of banks from 2010 to 2016 years were measured at 23 financial ratios.

The analysis results show that performance decreased in \% 50 of foreign capital banks in 2016 basis 2010. Generally, after 2014; profitability, quality of management and capital qualifications have decreased. It has been revealed that the liquidity adequacy and active qualifications has increased and the sensitivity to market risk has increased slightly. Although there is not much change in capital adequacy, some banks have been found to be below the sector average.

Keywords: CAMELS, Banks, Performance Analysis.

Jel Classification: C60, G21, P17

Makale Gönderim Tarihi: 07.07.2018

Makale Kabul Tarihi: 15.12.2018

\footnotetext{
* Dr. Öğr. Üyesi, Tokat Gaziosmanpaşa Üniversitesi, Turhal Uygulamalı Teknoloji ve

İşletmecilik Yüksekokulu, ali.uslu@gop.edu.tr, ORCID ID: 0000-0002-0739-0342.
} 


\section{GIRIŞ}

Finansal piyasaların en önemli ve en büyük aktörleri olan bankalar, bir ülkenin ekonomik durumu ve gelişimi açısından son derece önemli kurumlardır. Gelişmekte olan ekonomilerdeki finansal firsatlardaki artış yerel yatırımcıların yanı sıra yabancı yatırımcıların da ilgisini çekmiş, yeni pazarlara girme arzusu ile doğrudan ya da dolaylı olarak yabancı sermaye akışına sebep olmuştur.

Finansal krizlerin kaynağı ve krizlerden en çok etkilenen kurumlar finansal kurumlardır. Bu kurumlar; kredi, likidite, faiz, piyasa, kur, ülke, teknoloji, yönetim riski gibi pek çok riskle karşı karşıya kalmaktadırlar. Dolayısıyla bu kurumlarda ortaya çıkan yapısal bozulmalar piyasalarda kısa sürede ve şok etkisi ile kendini hissettirmekte ve etkileri ülke içinde, ülkenin bulunduğu bölgede yahut dünyada kendini göstermektedir. Kriz yönetiminin önemli bir parçası olan "öngörü” ile sorunlar henüz büyümeden kaynağında iken belirlenerek çözüm üretilebilecektir. Böylece hem kurumun geleceği garanti altına alınacak hem de kurum içinde denetim yapılmış olacaktır.

Yapılan çalışmada Türkiye'de kurulmuş olan 15 adet yabancı sermayeli bankadan verilerine tam olarak ulaşılabilen 12 bankanın 2010-2016 yıllarını kapsayan performansları kamu ve özel sektör kurumları tarafindan uzaktan denetim ve izleme amaciyla kullanılmakta olan CAMELS analizi yöntemiyle ölçülmüştür. Yapılan analiz ile yabancı bankaların performanslarının karşılaştırılması amaçlanmıştır. Böylece bankaların finansal durumları hakkında bilgiler edinilebilecektir.

Çalışmada Türkiye'deki bankacılık sektörünün gelişimi ve finansal büyüklüklerine ilişkin bilgiler verilmiş olup, ilerleyen bölümlerde yabancı sermayeli bankalar hakkında bilgilere değinilmiştir. Yapılan CAMELS analizi ile yabancı bankaların performansları değerlendirilmiş ve \% 50'sinde 2010 yılına göre 2016 yılında performans düşüşü olduğu gözlemlenmiştir.

\section{TÜRKIYYE'DE BANKACILIK SEKTÖRÜ}

Günümüzde bankacılık fonksiyonları her hangi bir ülkenin coğrafi sınırlarıyla kısıtlı değildir (Nimalathasan, 2008: 141). Bilişim teknolojisindeki gelişmeyle birlikte dünyada herhangi bir bankada veya finansal piyasada işlem yapmak artık çok kolaylaşmıştır. Hem bankalar hem de tasarruf sahipleri için aynı zamanda vakit ve maliyet avantajı da sunmaktadır.

Cumhuriyetten önce faaliyet gösteren bankalar yabancı sermayeli yahut yabancı iştirak olarak kurulmuş olup, bu bankaların, ülkemizde faaliyette bulunan şirketlere ve Osmanlı İmparatorluğu'na finansman desteği sağlamak amaciyla kuruldukları söylenebilir (Yurttadur ve Bulut, 2015: 167). Ülkemizde, sektöre yabancı bankaların girişi özellikle 1990'lı yıllar ve daha sonrasında belirgin bir hal almıştır. Bunun temelinde 1980'deki liberalizasyon sonucu ithalat ve ihracattaki artışlar ile Gümrük Birliği'nin etkisi vardır. Aslında, ülkemiz bankacılığının yurtdışına açılması ile yabancı bankaların Türkiye'ye gelişleri arasında paralellik vardır. $\mathrm{Bu}$ dönemde yabancı sermayenin ülkeye gelişini kolaylaştırıcı önlemler alınmış, ayrıca Beyrut gibi önemli bir finans merkezinin bu özelliğini yitirmesinden dolayı ülkemiz yabancı bankalar açısından eskiye oranla cazibe merkezi durumuna gelmiştir (İşeri ve 
Ulusan, 2007:133). Gelişmekte olan ülkelerde bankacılık sektöründe yabancıların payının özellikle 1990'lı yıllardan sonra hızlı oranda artış göstermesinin başlıca nedenleri arasında, bu ülkelerin serbestleşme politikaları sonucu getirilen kolaylıklar ve söz konusu ülkelere olan uluslararası sermaye akımları, yeni gelişen teknolojiler ve bankacılık krizleri gelmektedir. 1990'lı yıllarda Türk bankacılık sektörüne yabancı bankaların bu denli ilgisinin artmasındaki en önemli faktörler ise makro ekonomik dengelerde sağlanan istikrarla hızla yükselişe geçen Türk ekonomisi ve AB yolunda atılan kararlı adımlardır (Sakarya, 2010: 8).

Tablo 1. Türkiye'de Faaliyet Gösteren Bankaların Aktif Büyüklükleri (31/12/2017 itibariyle, milyon TL)

\begin{tabular}{|l|r|r|r|r|r|r|r|}
\hline & \multicolumn{1}{|c|}{$\mathbf{1 9 9 0}$} & \multicolumn{1}{c|}{$\mathbf{2 0 0 0}$} & \multicolumn{1}{c|}{$\mathbf{2 0 1 0}$} & \multicolumn{1}{c|}{$\mathbf{2 0 1 4}$} & \multicolumn{1}{c|}{$\mathbf{2 0 1 5}$} & \multicolumn{1}{c|}{$\mathbf{2 0 1 6}$} & $\mathbf{2 0 1 7}$ \\
\hline Kamu & 76 & 35.707 & 298.064 & 561.241 & 673.525 & 801.742 & 1.010 .197 \\
\hline Özel & 74 & 49.402 & 496.520 & 950.147 & 850.698 & 968.420 & 1.130 .145 \\
\hline Fon & --- & 8.698 & 791 & 2.059 & 3.069 & 2.937 & 2.628 \\
\hline Yabanc1 & 6 & 5.645 & 135.572 & 290.332 & 602.105 & 679.521 & 777.166 \\
\hline $\begin{array}{l}\text { Kalkınma ve } \\
\text { Yatırım }\end{array}$ & 15 & 4.637 & 30.929 & 84.529 & 106.597 & 142.729 & 174.902 \\
\hline $\begin{array}{l}\text { Toplam } \\
\text { Aktifler }\end{array}$ & 171 & 104.088 & 961.876 & 1.888 .308 & 2.235 .995 & 2.595 .348 & 3.095 .039 \\
\hline
\end{tabular}

Kaynak: TBB, 2018b

Bankaların aktif büyüklükleri 1990 yılında sadece 171 milyon TL iken 2000 yılında 100 milyar TL'yi geçmiş, 2010 yılında ise 1 trilyon TL'ye yaklaşmıştır. 2017 yıl sonu itibariyle de 3 trilyon TL'yi geçmiştir. BDDK'nın Nisan 2018 ayı verilerine göre Türkiye'de bankacılık sektörünün aktif büyüklüğü 3,4 trilyon TL olarak gerçekleşmiştir. Bankacılık sektörü büyümesini her geçen gün arttırarak sürdürmektedir.

Tablo 2. Türkiye' de Kurulmuş Bazı Yabancı Bankalar Hakkında Kısa Bilgiler

\begin{tabular}{|c|c|c|}
\hline Banka Adı & $\begin{array}{l}\text { Kuruluş } \\
\text { Yılı }\end{array}$ & Açıklama \\
\hline Alternatifbank A.Ş. & 1992 & $\begin{array}{l}1996 \text { yılında hisselerinin \% 80'i satın alınarak Anadolu Grubu'na geçmiştir. } \\
2013 \text { yılında Katar sermayeli Commercial Bank of Qatar'a (CBQ) } \\
\text { devredilmiştir. }\end{array}$ \\
\hline $\begin{array}{l}\text { Arap Türk Bankası } \\
\text { A.Ş. }\end{array}$ & 1976 & Arap (\% 65) ve Türk (\% 35) hissedarların ortak girişim bankasıdır. \\
\hline Burgan Bank A.Ş. & 1992 & $\begin{array}{l}\text { Bank Ekspres A.Ş. unvanı ile } 18 \text { Şubat } 1992 \text { tarihinde faaliyetine } \\
\text { başlamıştır. Tekfen Bank ve Eurobank Tekfen A.Ş. olarak faaliyetlerini } \\
\text { sürdürmüş } 2012 \text { yılında ise hisselerinin \% 99,26'si Kuveyt'li Burgan Bank } \\
\text { S.A.K. tarafından devralınmış ve unvanını Burgan Bank A.Ş. olarak } \\
\text { değişmiştir. }\end{array}$ \\
\hline Citibank A.Ş. & 1981 & $\begin{array}{l}\text { Türkiye'de şube olarak kurulmuş ve } 2004 \text { yılı itibariyle şube statüsünden } \\
\text { A.Ş. şeklinde iştirake dönüştürülmüştür. }\end{array}$ \\
\hline Denizbank A.Ş. & 1997 & $\begin{array}{l}2006 \text { tarihinde Zorlu Holding, Denizbank A.Ş.'de sahip olduğu hissesini } \\
\text { Belçika - Fransa sermayeli Dexia Participation Belgique S.A.'ya satmış, } \\
2012 \text { yılında Dexia Participation Belgique S.A.'ya ait \%99.85 hisselerinin } \\
\text { tamamı Rusya Federasyonunda mukim Sberbank Rossii (Sberbank) } \\
\text { tarafından satın alınmıştır. }\end{array}$ \\
\hline $\begin{array}{l}\text { Deutsche } \\
\text { A.Ş. }\end{array}$ & 1988 & $\begin{array}{l}\text { Türk Merchant Bank A.Ş. kalkınma ve yatırım bankası olarak faaliyetlerine } \\
\text { başlamıştır. Unvanı } 17 \text { Nisan } 1997 \text { tarihinde Bankers Trust A.Ş. olarak } \\
\text { değişmiştir. 1 Mart } 2000 \text { tarihinde unvanı Deutsche Bank A.Ş. olarak } \\
\text { değiştirerek Türkiye'de kurulmuş yabancı sermayeli bankalar grubuna } \\
\text { geçmiştir. }\end{array}$ \\
\hline $\begin{array}{ll}\text { QNB } & \text { Finansbank } \\
\text { A.Ş. } & \end{array}$ & 1987 & $\begin{array}{l}2016 \text { yllında Finans Bank A.Ş. sermayesinde National Bank of Greece'e ait } \\
\% \text { 82.33, NBGI Holding B.V.'ye ait \% 7.90, NBG Finance PLC'ye ait \% }\end{array}$ \\
\hline
\end{tabular}




\begin{tabular}{|c|c|c|}
\hline & & $\begin{array}{l}\text { 9.68; toplam \% } 99.81 \text { oranındaki hisselerin Katarlı Qatar National Bank } \\
\text { S.A.Q.'ya devretmiştir. Ticari unvanı, } 2018 \text { yılında QNB Finansbank A.Ş. } \\
\text { olarak değiştirilmiştir. }\end{array}$ \\
\hline HSBC Bank A.Ş. & 1990 & $\begin{array}{l}\text { Midland Bank A.Ş. olarak faaliyete başlamış olup, daha sonra unvanı } \\
\text { HSBC Bank olarak değişmiştir. } 2001 \text { yılında Demirbank'ı bünyesine } \\
\text { katmıştır. }\end{array}$ \\
\hline $\begin{array}{l}\text { ICBC Turkey Bank } \\
\text { A.Ş. }\end{array}$ & 1986 & $\begin{array}{l}\text { Tekstil Bank olarak kurulmuş olup, } 2015 \text { yılında Industrial and Commercial } \\
\text { Bank of China Limited tarafından devralınmıştır. }\end{array}$ \\
\hline ING Bank A.Ş. & 1984 & $\begin{array}{l}\text { İlk olarak The First National Bank of Boston Merkezi İstanbul Şubesi } \\
\text { olarak açılmış sonrasında ise The First National Bank of Boston A.Ş. } \\
\text { kurulmuş ve bu şubeyi devralmıştır. } 1991 \text { yılında Türk Boston Bank olarak } \\
\text { unvanını değiştirmiştir. } 1996 \text { yılında Oyak Bank A.Ş. olarak faaliyet } \\
\text { göstermiş } 2007 \text { yılında ING Bank N.V. satılmış ve unvanını ING Bank A.Ş. } \\
\text { olarak değiştirmiştir. }\end{array}$ \\
\hline $\begin{array}{l}\text { Turkland } \\
\text { A.Ş. }\end{array}$ & 1986 & $\begin{array}{l}\text { Bank of Bahrain and Kuwait B.S.C. adıyla kurulmuştur. } 1991 \text { yılında Bank } \\
\text { of Bahrain and Kuwait A.Ş. unvanını almıştır. } 1992 \text { yılında Tasarruf ve } \\
\text { Kredi Bankası A.Ş. unvanı ile faaliyetlerini sürdürmüştür. } 1994 \text { yılında } \\
\text { unvanı Garanti Yatırım ve Ticaret Bankası A.Ş. olarak değişmiştir. } 1997 \\
\text { yılında bankanın unvanı MNG Bank A.Ş. olarak değişmiştir. } 2006 \text { yılında } \\
\text { Arap Bank Plc ve Bank Med tarafından devralınmıştır. 2007'de unvanı } \\
\text { Turkland Bank A.Ş. olarak değiştirilmiştir. }\end{array}$ \\
\hline $\begin{array}{l}\text { Türkiye Garanti } \\
\text { Bankası A.Ş. }\end{array}$ & 1946 & $\begin{array}{l}2001 \text { yılında Osmanlı Bankası A.Ş.'yi bünyesine katmıştır. } 2005 \text { yılında } \\
\text { bankanın \% 25,5'ine karşılık gelen hisse senetleri General Electric Grubuna } \\
\text { satılmıştır. 2015 yılında İspanyada yerleşik Banco Bilbao Vizcaya } \\
\text { Argentaria SA (BBVA) çoğunluk hisselerini alarak hakim ortak konumuna } \\
\text { geçmiştir. }\end{array}$ \\
\hline
\end{tabular}
tarafindan oluşturulmuştur.

Tablo 2'de, incelenen yabancı sermayeli bankalara ait bilgiler verilmiştir. Tablo incelendiğinde Türkiye'de kurulmuş yabancı sermayeli bankalar genellikle yerli bankalarla ortaklık kurarak, bankanın çoğunluk hissesini alarak veya yerli bankaları satın alarak faaliyette bulundukları görülmektedir.

Tablo 3. Türkiye'de Faaliyet Gösteren Yabancı Sermayeli Banka Sayıları

\begin{tabular}{|c|c|c|c|c|c|c|c|c|c|c|}
\hline & $\mathbf{1 9 8 0}$ & $\mathbf{1 9 9 0}$ & $\mathbf{2 0 0 0}$ & $\mathbf{2 0 1 0}$ & $\mathbf{2 0 1 1}$ & $\mathbf{2 0 1 2}$ & $\mathbf{2 0 1 3}$ & $\mathbf{2 0 1 4}$ & $\mathbf{2 0 1 5}$ & $\mathbf{2 0 1 6}$ \\
\hline Yabancı Bankalar & $\mathbf{4}$ & $\mathbf{2 5}$ & $\mathbf{2 1}$ & $\mathbf{2 1}$ & $\mathbf{2 1}$ & $\mathbf{2 2}$ & $\mathbf{2 3}$ & $\mathbf{2 5}$ & $\mathbf{2 5}$ & $\mathbf{2 5}$ \\
\hline Türkiye'de Kurulan & 2 & 7 & 5 & 12 & 12 & 13 & 14 & 15 & 15 & 15 \\
\hline Türkiye'de Şube Açan & 2 & 16 & 13 & 5 & 5 & 5 & 5 & 6 & 6 & 6 \\
\hline Yatırım ve Kalkınma & 0 & 3 & 3 & 4 & 4 & 4 & 4 & 4 & 4 & 4 \\
\hline
\end{tabular}

Kaynak: TBB, 2005 ve TBB yıllık seçilmiş rasyolar kullanılarak yazar tarafindan oluşturulmuştur.

2018 yılı Haziran ayı itibariyle Türkiye'de bankacılık sektöründe 34 adet mevduat bankası, 13 adet kalkınma ve yatırım bankası ile 5 adet katılım bankası olmak üzere toplam 52 adet banka faaliyet göstermekte olup, 21 adet yabancı sermayeli mevduat bankasından 15 adedi Türkiye'de kurulmuş, 5 adedi ise Türkiye'de şube açmış bankalardır. Sektörün sayısal olarak \% 40'1 yabancı bankalardan oluşmaktadır. Mevduat bankaları içinde ise yabancı bankaların oranı \% 62'dir (TBB, 2018a: 1). 


\section{LITERATÜR}

CAMELS analizi uzaktan denetim ve gözetim faaliyetlerinin yapılması açısından denetimi yapan tarafindan uygulanması kolay olması nedeniyle kamu otoriteleri ile özel sektör şirketleri ve akademisyenler tarafindan kullanılmaktadır. Gerek ulusal gerekse uluslararası alanlarda yapılmış çalışmalardan bir kısmı aşağıda verilmiş̧ir.

Nurazi ve Evans (2005), CAMELS analizinin Endonezya'daki bankaların başarısızlığının tahminde kullanılıp kullanılamayacağını 1997 ekonomik krizini baz alarak 3 aşamalı olarak ortaya çıkarmaya çalışmışlardır. 1. aşamada Endonezya'daki ticaret bankalarının tamamının 1992-1996 dönemindeki performanslarını, 2. aşamada Endonezya'daki ticaret bankalarının tamamının 1993-1998 dönemindeki performanslarını son aşamada ise Jakarta Borsası'ndaki bankaların tamamının 1993-1998 dönemi performanslarını değerlendirmişlerdir. Araştırmanın sonucunda sermaye yeterlilik oranı, varlık kalitesi, yönetim, karlılık, likidite ve banka büyüklüğünün başarısızlığı istatistiksel olarak büyük oranda açıkladığını bu yüzden de hissedarların banka problemlerinin tanımlanması ve çözümünde bu oranlara odaklanmaları gerektiği kanaatine varmışlardır.

Sarker (2005), Endonezya'daki bankalar1 1997 kriz öncesi (1. kısım), kriz esnası ile kriz sonrası (2. kısım) ve son kısımda ise borsada işlem gören bankaların kriz esnası ve kriz sonrası dönemlerini 13 değişken kullanarak değerlendirmiştir. Analizde CAMELS sisteminin banka başarısızlığını ölçüp ölçemeyeceği amaçlanmıştır. İslami kıstasların düzenleyici ve denetçiler tarafindan benimsenmesi durumunda denetimin gücünü ve gözetimi geliştireceği ve aynı zamanda yeni bankacılık paradigmasında insanların güvenini arttıracağ 1 önerisinde bulunmuştur.

Jaffar ve Manarvi (2011), çalışmalarında Pakistan'da faaliyet gösteren 5 İslami ve 5 geleneksel (faiz) bankanın 2005-2009 yılları arası performanslarını CAMEL standartları ile karşılaştırmışlardır. Sonuçta geleneksel bankaların yönetim kalitesi ve karlılık açısından önde olduğunu buna karşın İslami bankaların sermaye yeterliliği ve likidite açısından daha iyi performansa sahip oldukları; varlık kalitesi bakımından da her iki grup bankaların neredeyse aynı performans derecesine sahip olduklarına ulaşmışlardır.

Aytekin ve Sakarya (2013), BİST’te işlem gören mevduat bankalarının 2001 ve 2008 krizleri öncesi ve sonrası dönemlerdeki performanslarını araştırdıkları çalışmalarında banka performanslarının kriz dönemlerinde dalgalanma gösterdiğini ve bankaların CAMELS puanları ve bileşenleri arasında istatistiki açıdan anlamlı farkın olmadığını tespit etmişlerdir.

Roman ve Şargu (2013), Romanya'daki 15 mevduat bankasının 2004-2011 yılları performanslarını CAMELS sistemi ile incelemişler ve araştırma sonucunda analize tabi tutulan bankaların güçlü yanlarını ve zayıf noktalarını vurgulamışlar ve karar vericilerin bankaların sağlamlıklarını iyileştirmek ve güçlendirme konusundaki kaygılarını arttırmalarının gerektiği kanatine varmışlardır. Seçilen bankaların iyi bir sermaye yapısının olduğu ve \% 19'un üzerinde yüksek ödeme kabiliyetine sahip olan en iyi beş bankanın RBS Bank, OTP Bank Romania, Banca Romaneasca, Alpha Bank ve CEC Bank olduğu bulgusuna ulaşmışlardır. 
Abdullayev (2013), Türkiye'de TMSF'ye devredilen bankalar haricindeki mevduat bankalarının 2005-2008 y1lları CAMELS performansını 18 adet referans gösterge ile değerlendirmiştir. Analizde piyasa riskine duyarlılık incelenen y1lların tamamında artan bir seviyede, olumlu ve yüksek etkinlik değerleri alan tek bileşen olmuştur.

Gümüş ve Nalbantoğlu (2015), Türkiye'deki bankaların 2002-2013 yılları aras1 performanslarını değerlendirmişlerdir. Yerli özel sermayeli bankaların en yüksek CAMELS değerine sahip olduğunu, kamu bankalarının da 2. sirada yer aldığını ve yabancı sermayeli bankalar ile katılım bankalarının zayıf bir görünüm gösterdikleri sonucuna ulaşmışlardır.

Ateşoğlu vd (2016), bankaların sınır ötesi birleşme ve satın almaların finansal performansları üzerindeki etkilerini CAMELS sistemi ile araştırmışlardır. Türkiye'deki üç bankanın satın alınma öncesi üç yıl ve satın alınma sonrası üç yıllık performansları analiz edilerek satın alınma sonrası dönemde yabancı bankalar tarafından satın alınan bankaların performanslarında düşüş olduğunu tespit etmişlerdir.

Gündoğdu (2017), 2015 yılında Türkiye'de aktifleri açısından 10 büyük bankanın 2005-2015 yılları arasındaki performanslarını CAMELS yöntemi ile değerlendirmiştir. 6 bankanın iyi bir performansa 4 bankanın ise kötü performansa sahip olduğu ortaya çıkarılmıştır.

Altemur vd. (2018), Türkiye'de aktif büyüklüklerine göre seçilen 10 yabancı sermayeli bankanın 2006-2016 yılları performanslarını CAMELS analizi ile ölçmüşlerdir. Bankaların 2008 yılına kadar etkin bir performans sergiledikleri, 2009-2012 yılları arasında kriz sebebiyle performansın düştüğü, 2013 yılı sonrasında ise yeniden düzelmeye başladığ 1 sonucuna ulaşmışlardır.

\section{CAMELS ANALİi̇}

Finansal kurumların faaliyetlerinin değerlendirilmesinde en yaygın kullanılan yöntemler; istatistiksel yöntemler, maliyet analizleri, uzman görüşleri ve analitik yöntemlerdir (Kavun ve Vorotintcev, 2016: 142). Bu yöntemler içinde kullanılan bazı teknikler ise, denetim dereceleri tahmin sistemi (SEER), Uzaktan CAMELS istatistiksel derecelemesi (SCOR), büyüme izleme sistemidir (GMS) (Çinko ve Avc1, 2008: 28). CAMELS adıyla bilinen yöntem ilk olarak 1979 yılında ABD'de Federal Reserve (FED), Federal Deposit Insurance Commission (FDIC), U.S. Department of the Treasury, Office of the Comptroller of the Currency (OCC) gibi bankaları düzenleyen ve denetleyen kurumlar tarafindan oluşturulmuş ve daha sonra farklı ülkelerin denetim otoriteleri tarafindan finansal kurumların durumunu belirlemek için faydalı bir araç olarak görülmüştür (Sarker, 2005: 6) (Lopez, 1999) (Roman ve Şargu, 2013: 704) (https:// www. fdic.gov/about/strategic/strategic/mission.html) (https://www.occ. treas. gov/about/what -we-do/mission/index-about.html) (https://www. federalreserve. gov/aboutthefed.htm). CAMELS adıyla yaygın olarak kullanılan yöntemin orijinal adı The Uniform Financial Instituons Rating System (UFIRS, finansal kuruluşlar tekdüzen dereceleme sistemi)'dir. UFIRS, finansal, kurumsal ve kanunlara uyum faktörlerini göz önüne alan ve finansal kurumları ayrıntılı ve standart olarak değerlendirmeyi amaçlamaktadır. $\mathrm{Bu}$ sistemin finansal kurumların sağlamlığını değerlendirmede standart bazda efektif bir dâhili denetim aracı olduğu Federal Financial Institution Examination Council (FFIEC) tarafindan genel kabul görmüştür (BDDK, 2018b: 1). 
CAMELS analizi altı bileşenden oluşan, firma veya kurumun performans değerlendirme, gözetim ve denetim gibi faaliyetlerinin değerlendirilmesinde kullanılan bir oran yaklaşımıdır (Çağıl ve Mukhtarov, 2014; 81). Orijinal UFIRS kapsamında bir bankaya beş alanda performansa dayalı derecelendirmeler yapılmıştır (Rao, 2018: 68). 1996 yılında eklenen piyasa riskine duyarlılık bileşeniyle birlikte altı bileşenin, bileşen derecesi ve değerlendirmesine dayalı bir bileşik derece verilmektedir. Bu bileşenler; sermaye yeterliliği (C), aktif kalitesi (A), yönetim kabiliyeti (M), gelir gider dengesi ve kârlılık (E), likidite (L) ve piyasa riskine duyarlılık (S) ile ifade edilmektedir (BDDK, 2018b: 1). CAMELS değerlendirmesinde ölçek 1-5 arası puanlarla oluşturulmaktadır. En iyi performans notu 1'i en kötü performans puanı ise 5 ile ifade edilmektedir. Bileşenlerin tümü için böyle bir çözümleme yapıldıktan sonra bileşenlerin notlarının ağılıklı ortalaması alınarak, bankayı değerlendirmeye esas olan genel puanı ortaya çıkmaktadır. Değerlendirmede kullanılan ağırlıklar bankanın yapısı, büyüklüğü gibi özellikler dikkate alınarak araştırmacı veya denetçi tarafindan oluşturulmaktadır (Altemur vd., 2018: 61).

CAMELS bileşenleri sonucu elde edilen sonuçların değerlendirilmesinde göz önünde bulundurulan kistaslar şöyledir (Ahmedov ve Memmedov, 2017: 100).

"1" her açıdan güçlüdür (her bileşen için not 1 ya da 2 olmalıdır.).

"2" genel olarak güçlüdür (her bileşen değeri 3'ten kötü olmamalıdır.).

"3" bankanın etkinliği ile ilgili sorunlar bulunmaktadır. Olası şoklara karşı yeterli seviyede dayanıklı değildir. Denetçiler, yöneticiler sorunlu alanlara önem vermelidirler.

"4" genel olarak ciddi problemler vardır. Finansal ve yönetimsel bozukluklar yaşanmakta olup, banka performansı kötüdür.

"5" çok ciddi mali yahut yönetimsel sorunlar mevcut olup, batma riski yüksektir.

\section{5. ÇALIŞMANIN KISITLARI VE METODOLOJİSI}

Çalışmada bankaların performanslarının analizinde kullanılan oran analizi ve bu bağlamda CAMELS derecelendirme yöntemi Türkiye'de kurulmuş 12 yabancı sermayeli mevduat bankasının 2010-2016 yılları arası faaliyet dönemlerini kapsayacak şekilde uygulanmıştır. Türkiye Bankalar Birliği'nin Mart 2018 verilerine göre Türkiye'de şube açan 6 adet yabanc1 sermayeli mevduat bankası, 15 adet Türkiye'de kurulmuş yabancı sermayeli mevduat bankası ve 4 adet yabancı sermayeli kalkınma ve yatırım bankası faaliyet göstermektedir. Araştırmaya Türkiye'de faaliyet gösteren yabancı sermayeli bankalardan aktif yapıları, şube sayıları ve personel sayıları gibi büyüklükleri ile sektörü temsil edebilme kabiliyetleri açısından sadece Türkiye'de kurulmuş yabancı sermayeli mevduat bankaları dâhil edilmiştir. Ayrıca analizde kullanılan bankaların tamamı analiz yapılan dönemler boyunca yabancı sermayeli bankalar değildirler. Ancak Türkiye Bankalar Birliği'nin Mayıs 2018 y1lı verilerine göre bu bankaların tamamı yabancı sermayeli bankalar olarak faaliyetlerini sürdürmektedirler.

Tablo 4. Analizde Kullanılan Yabancı Sermayeli Mevduat Bankaları

\begin{tabular}{|l|l|}
\hline Alternatifbank A.Ş. & HSBC Bank A.Ş. \\
\hline Arap Türk Bankası A.Ş. & ICBC Turkey Bank A.Ş. \\
\hline Burgan Bank A.Ş. & ING Bank A.Ş. \\
\hline Citibank A.Ş. & Turkland Bank A.Ş. \\
\hline Denizbank A.Ş. & Türkiye Garanti Bankası A.Ş. \\
\hline Deutsche Bank A.Ş. & QNB Finansbank A.Ş. \\
\hline
\end{tabular}


Analiz öncesinde bankaların CAMELS bileşenlerinin alt bileşenleri ve ağırlıkları literatür de dikkate alınarak belirlenmiş ve tablo 5 'te gösterilmiştir.

Tablo 5. Analizde Kullanılan Finansal Oranlar ve Ağırlıkları

\begin{tabular}{|c|c|c|c|}
\hline Değişkenler & Kod & $\begin{array}{l}\text { İlişki } \\
\text { Yönü }\end{array}$ & $\begin{array}{c}\text { Ağırlıklar } \\
(\%)\end{array}$ \\
\hline C - Capital (Sermaye Yeterliliği) & SY & & 20 \\
\hline Sermaye Yeterliliği Oranı & SY1 & + & 30 \\
\hline Özkaynaklar / Toplam Aktifler & SY2 & + & 30 \\
\hline (Özkaynaklar - Duran Aktifler) / Toplam Aktifler & SY3 & + & 20 \\
\hline Özkaynaklar/(Mevduat+Mevduat Dışı Kaynaklar) & SY4 & + & 20 \\
\hline A - Asset (Aktif Kalitesi) & VK & & 20 \\
\hline Finansal Varlıklar (Net) / Toplam Aktifler & VK1 & + & 30 \\
\hline Toplam Krediler ve Alacaklar / Toplam Aktifler & VK2 & + & 25 \\
\hline Toplam Krediler ve Alacaklar / Toplam Mevduat & VK3 & + & 25 \\
\hline Duran Aktifler / Toplam Aktifler & VK4 & + & 20 \\
\hline M - Management (Yönetim Kalitesi) & YK & & 10 \\
\hline Takipteki Krediler (Brüt) / Toplam Krediler ve Alacaklar & YK1 & - & 30 \\
\hline Şube Başına Net Kâr & YK2 & + & 30 \\
\hline Toplam Mevduat / Toplam Aktifler & YK3 & - & 20 \\
\hline Faiz Dışı Gelirler (Net) / Diğer Faaliyet Giderleri & YK4 & + & 20 \\
\hline E - Earnings (Kârlııık) & KR & & 15 \\
\hline Ortalama Aktif Kârlılı̆̆ & KR1 & + & 30 \\
\hline Ortalama Özkaynak Kârllılı̆ı & KR2 & + & 30 \\
\hline Vergi Öncesi Kâr / Toplam Aktifler & KR3 & + & 20 \\
\hline Toplam Gelirler / Toplam Giderler & KR4 & + & 20 \\
\hline L - Liquidity (Likidite) & LT & & 25 \\
\hline Likit Aktifler / Toplam Aktifler & LT1 & + & 35 \\
\hline Likit Aktifler / Kısa Vadeli Yükümlülükler & LT2 & + & 35 \\
\hline TP Likit Aktifler / Toplam Aktifler & LT3 & + & 30 \\
\hline S - Sensitivity to Market Risk (Piyasa Riskine Duyarlılık) & RD & & 10 \\
\hline YP Likit Aktifler / YP Pasifler & RD1 & + & 20 \\
\hline Net Bilanço Pozisyonu / Özkaynaklar & RD2 & - & 30 \\
\hline Özel Karşılıklar Sonrası Net Faiz Geliri / Toplam Faaliyet Geliri & RD3 & + & 30 \\
\hline Faiz Geliri / Toplam Aktifler & RD4 & + & 20 \\
\hline
\end{tabular}

\section{CAMELS ANALIZİ SONUÇLARI}

Bankaların CAMELS derecelendirme sonuçları hesaplanır iken tablo 5 'te belirtilen 23 finansal oran, bileşenlere verilen önem derecelerine göre yüzdesel olarak literatür de dikkate alınarak göreceli bir şekilde belirlenmiştir.

Elde edilen CAMELS alt bileşenlerini özet olarak şöyle açıklayabiliriz.

\subsection{Sermaye Yeterliliği $(C)$}

5411 sayılı Bankacılık Kanunu'na göre maruz kalınan riskler nedeniyle oluşabilecek zararlara karşı yeterli özkaynak bulundurulması sermaye yeterliliğini ifade etmektedir. Bankalar, BDDK tarafindan düzenlenecek yönetmelikte öngörülen usûl ve esaslara göre \% 8 oranından az olmamak üzere belirlenecek sermaye yeterliliği oranını hesaplamak, tutturmak, idame ettirmek ve raporlamak zorundadir. 
TBB verilerine göre 2016 yılı için Türkiye'de kurulmuş yabancı sermayeli bankaların sermaye yeterliliği \% 16,7 olarak belirlenmiştir (TBB, 2018d).

Tablo 6. Sermaye Yeterliliği Değerleri

\begin{tabular}{l|r|r|r|r|r|r|r|}
\hline \multicolumn{1}{|c|}{ Banka } & $\mathbf{2 0 1 0}$ & $\mathbf{2 0 1 1}$ & $\mathbf{2 0 1 2}$ & $\mathbf{2 0 1 3}$ & $\mathbf{2 0 1 4}$ & $\mathbf{2 0 1 5}$ & $\mathbf{2 0 1 6}$ \\
\hline Alternatifbank & $-3,94$ & $-6,88$ & $-7,54$ & $-6,84$ & $-2,03$ & $-4,67$ & $-4,21$ \\
\cline { 2 - 8 } Arap Türk Bankas1 & 19,02 & 2,40 & 4,63 & 5,43 & 7,04 & 7,93 & 4,37 \\
\cline { 2 - 8 } Burgan Bank & $-2,96$ & 0,28 & 0,96 & $-2,50$ & 1,45 & $-2,03$ & $-4,15$ \\
\cline { 2 - 8 } Citibank & 3,34 & 2,12 & 2,67 & 15,97 & 14,09 & 8,78 & 9,33 \\
\cline { 2 - 8 } Denizbank & $-2,74$ & $-1,76$ & $-3,10$ & $-4,39$ & $-3,84$ & $-2,52$ & $-2,48$ \\
\cline { 2 - 8 } Deutsche Bank & 11,39 & 14,46 & 48,39 & 17,22 & 17,83 & 12,90 & 9,42 \\
\cline { 2 - 8 } HSBC Bank & 1,88 & $-0,12$ & $-0,50$ & $-2,20$ & $-1,60$ & $-2,47$ & $-0,51$ \\
\cline { 2 - 8 } ICBC Turkey Bank & 6,83 & 2,89 & 2,48 & 9,76 & 12,32 & $-3,03$ & $-3,41$ \\
\cline { 2 - 8 } ING Bank & $-2,44$ & $-1,63$ & $-1,58$ & $-0,54$ & $-1,37$ & $-1,42$ & $-0,08$ \\
\cline { 2 - 7 } Turkland Bank & 0,24 & 5,23 & $-0,83$ & 5,13 & 9,07 & 2,66 & 2,75 \\
\cline { 2 - 6 } Türiye Garanti Bankas1 & 0,81 & 0,27 & 1,04 & 1,88 & 3,07 & 2,00 & 1,81 \\
\cline { 2 - 4 } QNB Finansbank & 0,40 & 1,06 & 1,55 & 3,42 & 2,56 & 0,01 & $-2,04$ \\
\hline
\end{tabular}

Türkiye'de kurulmuş yabancı sermayeli bankaların hesaplanan CAMELS sermaye yeterliliği değerleri (Sermaye Yeterliliği, Özkaynaklar/Toplam Aktifler, (Özkaynaklar-Duran Aktifler)/Toplam Aktifler, Özkaynaklar/(Mevduat+Mevduat Dışı Kaynaklar) tablo 6'da görüldüğü gibi olup, Deutsche Bank'ın sermaye yeterliliği 2016 yılında düşse de diğer bankalardan daha iyi bir performans sergilemiştir. Özkaynakların sürekli arttırılması faaliyetler açısından gerekli ve zorunlu olmakla birlikte tamamen veya sürekli olarak ödenmiş sermaye ile arttırmak ta mümkün değildir. Dağıtılmayan kârların sermayeye eklenmesi de özsermaye artışını sağlamakta olup, incelenen bankaların \% 58'sinde kârlılığın düşüşü bu bileșenin sınırlı olarak kalmasında etkin bir rol oynadığı söylenebilir.

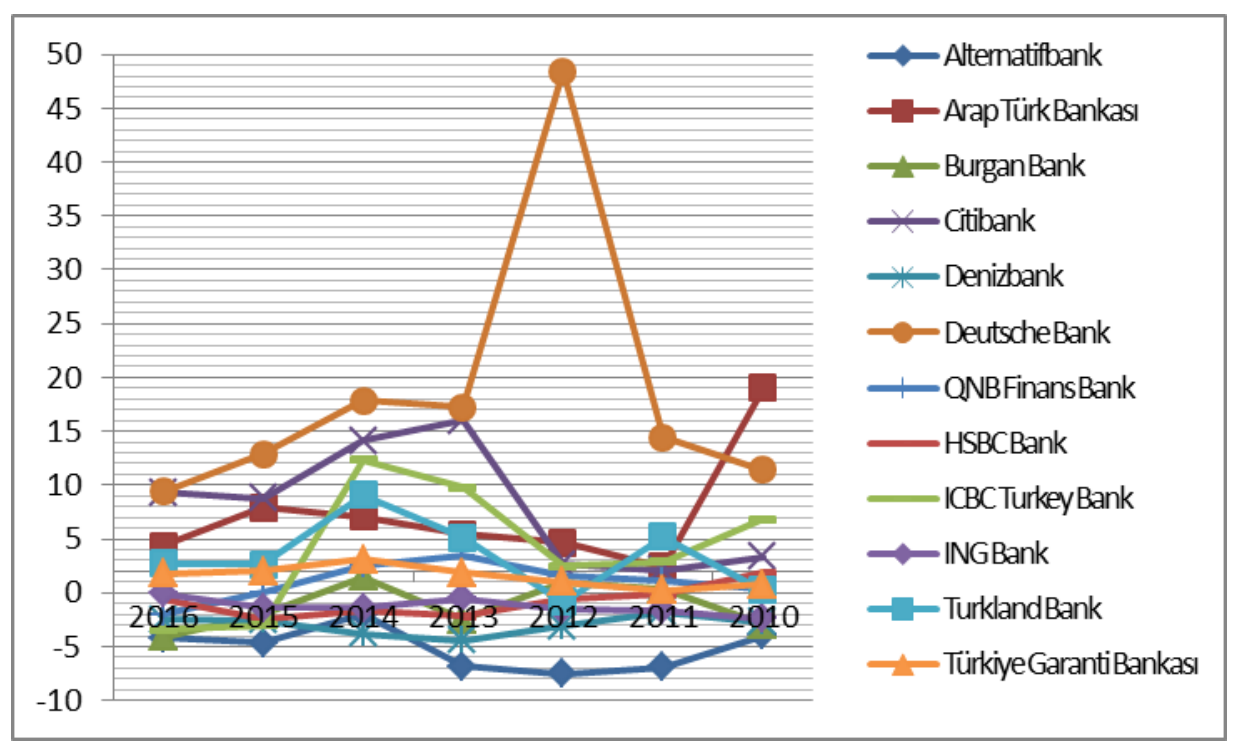

Şekil 1. Bankaların Sermaye Yeterlilikleri 
Özellikle 2014 y1lından itibaren bu bileşenin gerilediği görülmektedir. En dikkat çeken banka 2012 yılında sermaye yeterlilik bileşenini yaklaşık 35 puan arttıran Deutsche Bank'ın bu yıldan itibaren düşüş trendine girmesidir. Citibank 2013 yılında bileşen skorunu yaklaşık 14 puan arttırmış ve en dikkat çeken ikinci banka olmuştur. Arap Türk Bankası ise 2011 yılında 17 puanlık düşüş göstermiş sonraki yıllarda eski seviyesine gelemese de az da olsa toparlanmıştır. Diğer bankalar ise incelenen dönemler itibariyle dalgalı bir seyir izleseler de CAMELS sermaye seterliliği bileşeni skorları pek fazla değişmemiştir.

\subsection{Aktif Kalitesi (A)}

Kredi ve yatırım portföylerindeki kredi risklerinin, maddi ve maddi olmayan varlıkların ve bilânço dışı işlemler gibi diğer aktiflerin kalitesini yansıtmaktadır. Elde edilen fonların alternatif yatırım araçları arasından en yüksek verimi verecek şekilde dağıtılmasıyla aktif kalitesinin yükseltilmesi amaçlanmaktadır (Arıçelik, 2010: 80). Bankacılık sektöründe aktiflerin değer kaybetmesi risk olarak tanımlanmaktadır (Aytekin ve Sakarya, 2013: 35).

Tablo 7. Aktif Yeterliliği Değerleri

\begin{tabular}{l|r|r|r|r|r|r|r|}
\hline \multicolumn{1}{|c|}{ Banka } & $\mathbf{2 0 1 0}$ & $\mathbf{2 0 1 1}$ & $\mathbf{2 0 1 2}$ & $\mathbf{2 0 1 3}$ & $\mathbf{2 0 1 4}$ & $\mathbf{2 0 1 5}$ & $\mathbf{2 0 1 6}$ \\
\hline Alternatifbank & 1,95 & 2,83 & 3,36 & 2,98 & 0,96 & $-1,37$ & $-0,67$ \\
\cline { 2 - 8 } Arap Türk Bankası & 8,62 & $-8,20$ & $-6,51$ & $-6,81$ & $-7,69$ & $-7,87$ & $-5,73$ \\
\cline { 2 - 8 } Burgan Bank & 6,03 & 5,96 & $-0,30$ & 3,02 & 1,90 & $-1,04$ & $-1,18$ \\
\cline { 2 - 8 } Citibank & $-8,12$ & $-7,60$ & $-7,96$ & $-7,12$ & $-11,19$ & $-8,07$ & $-8,35$ \\
\cline { 2 - 8 } Denizbank & 1,28 & 1,70 & 2,74 & 1,63 & 2,31 & 3,07 & 1,56 \\
\cline { 2 - 8 } Deutsche Bank & $-13,35$ & 11,04 & 9,75 & 6,76 & 1,27 & 2,59 & 4,72 \\
\cline { 2 - 8 } HSBC Bank & $-1,17$ & $-3,25$ & $-1,06$ & $-3,33$ & $-5,62$ & $-4,96$ & $-4,21$ \\
\cline { 2 - 8 } ICBC Turkey Bank & 1,42 & 0,14 & $-0,58$ & $-1,50$ & $-2,23$ & 1,25 & 1,45 \\
\cline { 2 - 8 } ING Bank & 0,68 & $-0,29$ & $-0,78$ & $-0,36$ & $-0,24$ & $-1,58$ & $-1,96$ \\
\cline { 2 - 7 } Turkland Bank & $-1,57$ & $-2,42$ & $-3,45$ & $-0,95$ & 1,20 & $-1,51$ & $-2,27$ \\
\cline { 2 - 6 } Garanti Bankas1 & 1,81 & 1,70 & 2,75 & 2,06 & 3,23 & 1,11 & 1,23 \\
\cline { 2 - 7 } QNB Finansbank & 1,13 & 1,74 & 0,76 & 2,31 & 4,30 & 1,50 & 1,68 \\
\hline
\end{tabular}

Genel olarak bileșen puanı dalgalı bir seyir izleyip bankaların \% 67'sinde düşse de 2016 yılında varlık kalitesinin hafif şekilde yükselmeye başladığ 1 görülmektedir. Tabloda göze çarpan Deutsche Bank diğer bankalara göre büyük bir performans göstererek negatif değerden pozitif değere geçer iken, Burgan Bank'ın performansının ise pozitif değerden negatif değere gerilediği görülmektedir. 


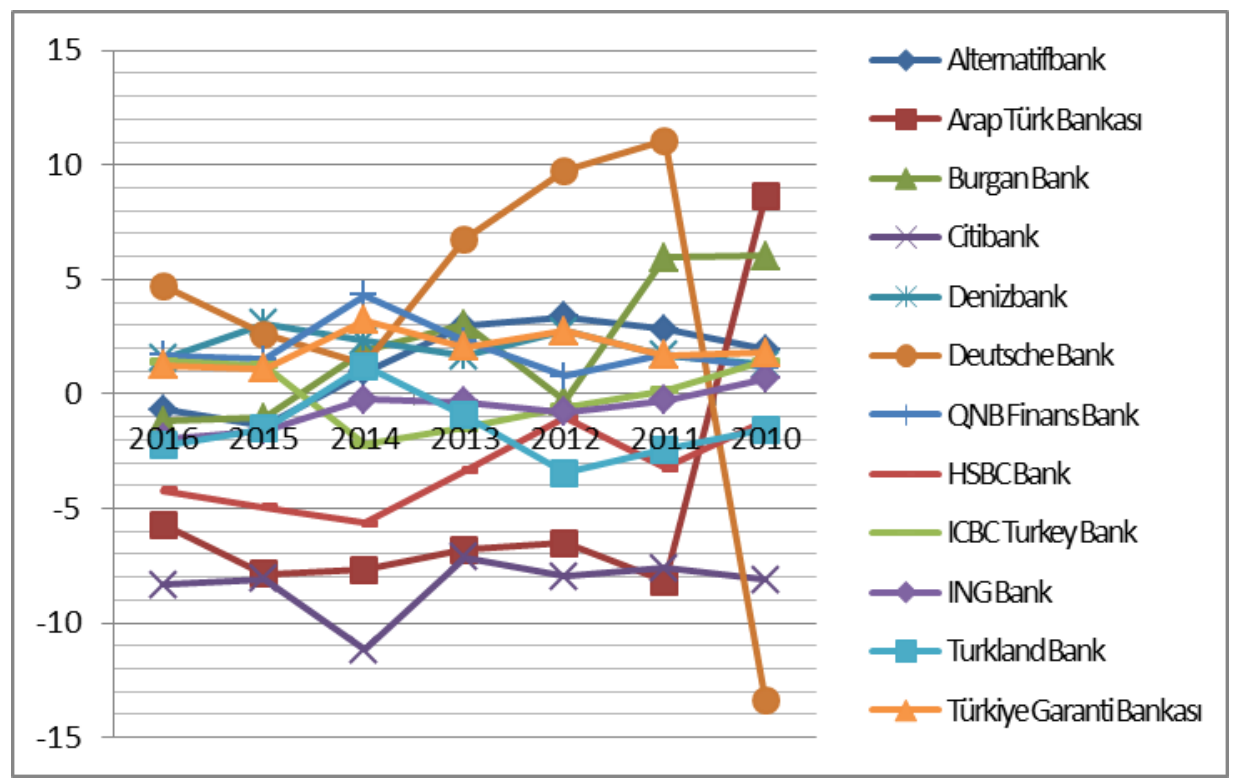

Şekil 2. Bankaların Aktif Kalitesi

İncelenen dönemler içinde aktif kalitesinin (Finansal Varlıklar (Net)/Toplam Aktifler, Toplam Krediler ve Alacaklar/Toplam Aktifler, Toplam Krediler ve Alacaklar/Toplam Mevduat, Duran Aktifler/Toplam Aktifler) Denizbank, Deutsche Bank, QNB Finansbank ve ICBC Turkey Bank'ın bu endekse ait puanını yükselttikleri görülmüştür. Bu bankalardan Deutsche Bank, Burgan Bank ve Arap Türk Bankası hariç diğerlerinin aktif yeterliliğinde pek fazla bir değişiklik gözlemlenmemiş olup, Deutsche Bank'ın skoru 2011 yılında büyük bir sıçrayış göstererek negatif değerden (-13) pozitif (11) değere geçmiş, bu banka sonraki yıllarda da bu puanı koruyamayıp 2016 yılında puanı yaklaşık 5'e düşmüştür. Diğer bankaların bu bileşen puanları ise 2016 yılı dikkate alındığında 2010 yılına göre düşüş göstermiştir. Bileşende krediler ve alacaklara verilen yüzdesel değer dikkate alındığında kredilerin ve alacakların tahsilâtında sorunların olduğu ve yönetim kalitesinde de düşüş olması varlık kalitesini olumsuz etkilediği yorumu yapılabilir.

\subsection{Yönetim Kalitesi (M)}

Bankalar ülke içinde önemli bir sektörde faaliyette bulunmaktadırlar. Bankalar da ticari bir şirket olmaları sebebiyle kâr elde etmek ve kârlarını arttırmak, verdikleri kredileri tahsil etmek, mevduatları arttırmak gibi amaçları bulunmaktadır. Bu amaçlar; iyi bir iç denetim sistemi, kurumsal risk yönetiminin kabulü, uygulanması ve iyi bir yönetimin varlığıyla gerçekleştirilebilecektir.

Tablo 8. Yönetim Kalitesi Değerleri

\begin{tabular}{l|r|r|r|r|r|r|r|}
\hline \multicolumn{1}{|c|}{ Banka } & $\mathbf{2 0 1 0}$ & $\mathbf{2 0 1 1}$ & $\mathbf{2 0 1 2}$ & $\mathbf{2 0 1 3}$ & $\mathbf{2 0 1 4}$ & $\mathbf{2 0 1 5}$ & $\mathbf{2 0 1 6}$ \\
\hline Alternatifbank & 1,33 & $-2,41$ & 0,21 & 2,62 & 2,09 & $-1,16$ & $-2,82$ \\
\cline { 2 - 8 } Arap Türk Bankası & 16,30 & 24,32 & 22,31 & 33,57 & 33,72 & 19,21 & 7,44 \\
\cline { 2 - 8 } Burgan Bank & $-1,04$ & 0,32 & $-4,02$ & $-4,70$ & $-1,71$ & $-1,08$ & $-1,44$ \\
\cline { 2 - 8 } Citibank & 1,51 & $-9,43$ & 0,64 & 45,32 & 53,82 & 36,42 & 24,06 \\
\cline { 2 - 8 } Denizbank & 1,40 & 2,26 & 1,55 & 0,93 & $-0,56$ & $-2,13$ & $-2,20$ \\
Deutsche Bank & $-19,78$ & 81,11 & 256,70 & 7,14 & 263,37 & 135,90 & 71,03 \\
\cline { 2 - 7 } HSBC Bank & $-1,89$ & $-0,78$ & $-2,37$ & $-3,46$ & $-4,88$ & $-6,12$ & $-11,49$ \\
\cline { 2 - 7 } & & & & & & &
\end{tabular}




\begin{tabular}{l|r|r|r|r|r|r|r|}
\hline ICBC Turkey Bank & $-1,19$ & $-1,84$ & $-2,83$ & 1,28 & $-5,47$ & $-4,95$ & $-2,14$ \\
\cline { 2 - 7 } ING Bank & $-2,86$ & $-2,02$ & $-0,11$ & 0,05 & $-0,92$ & $-2,46$ & $-1,05$ \\
\cline { 2 - 7 } Turkland Bank & $-0,34$ & $-1,91$ & $-1,77$ & 0,33 & 0,73 & $-4,94$ & $-5,39$ \\
\cline { 2 - 7 } Türkiye Garanti Bankas1 & 14,47 & 10,69 & 8,52 & 14,54 & 10,16 & 4,90 & 3,58 \\
\cline { 2 - 7 } QNB Finansbank & 2,75 & 0,40 & 0,14 & 0,68 & 1,59 & $-3,34$ & $-2,96$ \\
\hline
\end{tabular}

İncelenen bankaların \% 75'inin yönetim kalitesi puanında (Takipteki Krediler (Brüt)/Toplam Krediler ve Alacaklar, Şube Başına Net Kâr, Toplam Mevduat/Toplam Aktifler, Faiz Dışı Gelirler (Net)/Toplam Aktifler) düşüş olduğu gözlemlenmiştir. Arap Türk Bankası, Citibank, Deutsche Bank hariç diğer bankaların yönetim kalitesinde pek bir değişiklik olmayıp incelenen dönemler boyunca düşüş olsa da neredeyse stabil kaldığ söylenebilir.

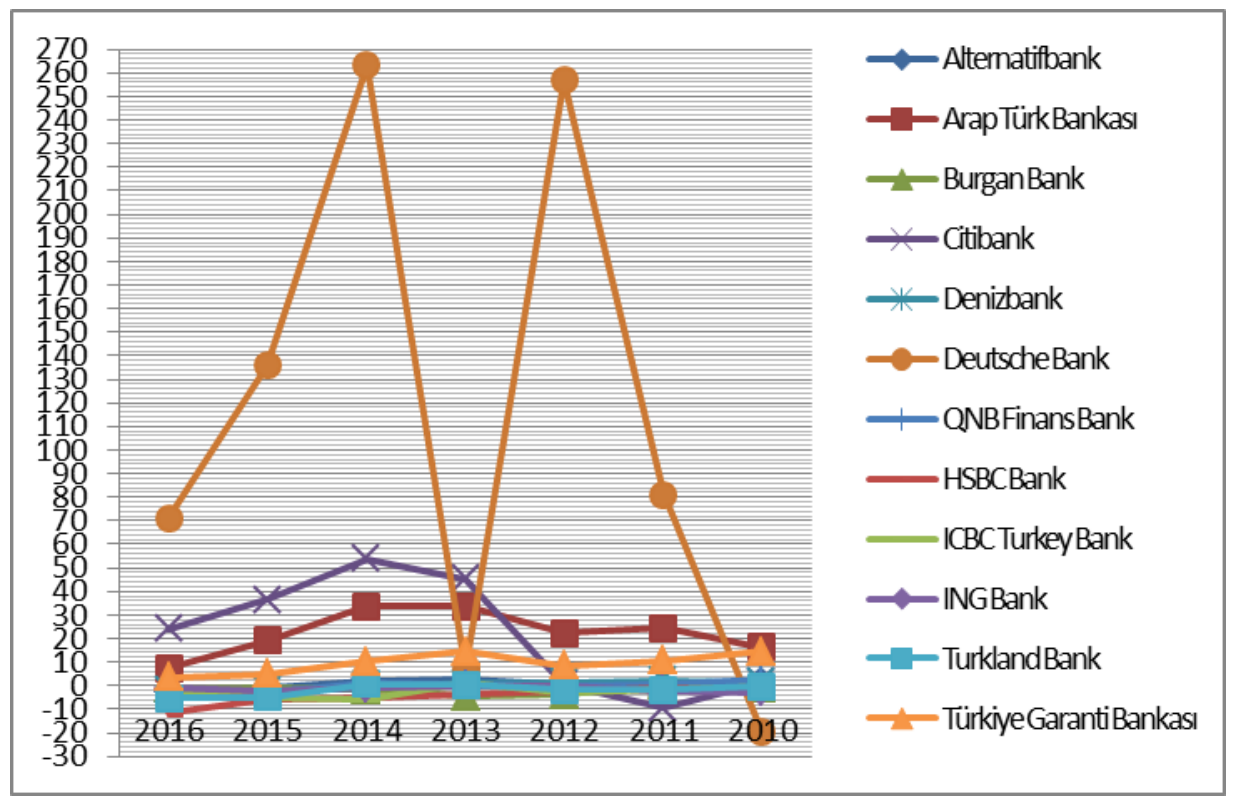

Şekil 3. Bankaların Yönetim Kalitesi

Yapılan hesaplamalar ayrıntılı incelendiği zaman 2014 yılı, bankalar için kırılganlığın başladığ 1 yıl olmuş ve bu yıldan sonra yönetim kalitesi puanları düşmeye başlamıştır. Bu düşüş de varlık kalitesini ve kârlılığı olumsuz etkilemiştir.

\subsection{Kârlılık (E)}

$\mathrm{Bu}$ bileşen, kazançların verimliliğini ve tarihsel değişimini değerlendirirken mevcut yapının sürdürülebilirliğini de dikkate almaktadır (Türker Kaya, 2001: 4). 
Tablo 9. Kârlılık Değerleri

\begin{tabular}{l|r|r|r|r|r|r|r|}
\hline \multicolumn{1}{|c|}{ Banka } & $\mathbf{2 0 1 0}$ & $\mathbf{2 0 1 1}$ & $\mathbf{2 0 1 2}$ & $\mathbf{2 0 1 3}$ & $\mathbf{2 0 1 4}$ & $\mathbf{2 0 1 5}$ & \multicolumn{1}{c|}{$\mathbf{2 0 1 6}$} \\
\hline Alternatifbank & $-6,44$ & $-7,09$ & $-2,25$ & 6,65 & 9,75 & $-5,97$ & $-11,92$ \\
\cline { 2 - 8 } Arap Türk Bankası & 2,70 & 5,67 & 5,55 & 15,27 & 17,65 & 7,09 & 0,63 \\
\cline { 2 - 8 } Burgan Bank & $-9,38$ & $-5,81$ & $-12,32$ & $-24,86$ & $-10,96$ & $-6,48$ & $-6,93$ \\
\cline { 2 - 8 } Citibank & $-0,78$ & $-11,83$ & $-2,74$ & 4,33 & 17,40 & 9,23 & 7,56 \\
\cline { 2 - 8 } Denizbank & 3,59 & 8,52 & 4,87 & 4,50 & 2,26 & $-1,20$ & 1,31 \\
\cline { 2 - 8 } Deutsche Bank & $-14,41$ & $-1,90$ & 32,23 & $-10,72$ & 27,80 & 11,63 & 4,98 \\
\cline { 2 - 8 } HSBC Bank & $-1,10$ & $-3,07$ & $-6,24$ & $-10,12$ & $-14,73$ & $-23,27$ & $-24,64$ \\
ICBC Turkey Bank & $-8,13$ & $-7,05$ & $-6,65$ & 5,88 & $-7,76$ & $-15,66$ & $-10,66$ \\
\cline { 2 - 8 } ING Bank & $-6,85$ & $-8,77$ & $-3,12$ & $-1,67$ & $-4,20$ & $-9,14$ & $-1,25$ \\
\cline { 2 - 8 } Turkland Bank & $-10,98$ & $-10,95$ & $-8,58$ & $-5,52$ & $-2,75$ & $-9,70$ & $-10,58$ \\
Türkiye Garanti Bankasi & 9,96 & 6,70 & 4,25 & 17,07 & 11,20 & 3,08 & 4,15 \\
\cline { 2 - 7 } QNB Finansbank & 9,13 & 4,23 & 2,37 & 8,73 & 6,64 & $-2,61$ & $-0,52$ \\
\hline
\end{tabular}

Citibank ve Deutsche Bank'in skoru incelenen dönemler boyunca negatif değerden pozitife geçerek diğer bankalara göre performansını daha fazla arttırdığı; HSBC Bank, QNB Finansbank ve ING Bank'ın ise kârlılık performanslarının diğer bankalara göre daha fazla düştüğü gözlemlenmiştir.

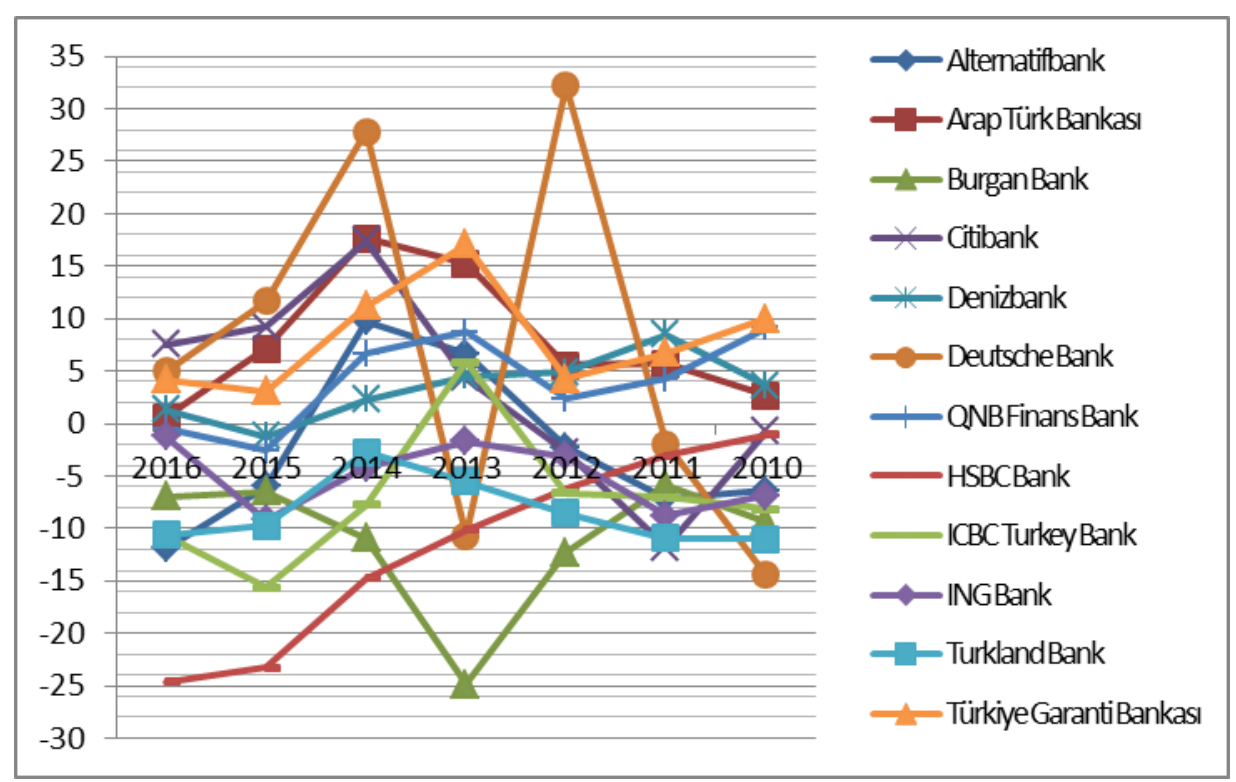

Şekil 4. Bankaların Kârlılığı

İnceleme dönemleri boyunca bankaların çoğunluğunun kârlılık derecesinin (Ortalama Aktif Kârlılığı, Ortalama Özkaynak Kârlılı̆̆1, Vergi Öncesi Kâr/Toplam Aktifler, Toplam Gelirler/Toplam Giderler) düştüğü gözlemlenmiştir. Yöneticilerin aldı̆̆ 1 kararların kârlılı̆̆ büyük oranda etkilemesi sebebiyle ve incelenen bankaların \% 75 'inin yönetim kalitesinin düşüş göstermesi de bu bileşenin olumsuz etkilendiğinin göstergesi olabilmektedir. 


\subsection{Likidite (L)}

Bankanın faaliyetini sürdürebilmesi açısından yükümlülüklerini yerine getirememesi olasılı̆̆ına karşı bu bileşen en az sermaye yeterliliği bileşeni kadar önemlidir (Aytekin ve Sakarya, 2013: 36). 5411 sayılı Bankacılık Kanunu'na göre Bankalar, Merkez Bankası'nın uygun görüşü alınmak suretiyle BDDK tarafından belirlenecek usûl ve esaslara göre asgarî likidite düzeyini hesaplamak, tutturmak, idame ettirmek ve raporlamak zorundadır.

Tablo 10. Likidite Değerleri

\begin{tabular}{|l|r|r|r|r|r|r|r|}
\hline \multicolumn{1}{|c|}{ Banka } & $\mathbf{2 0 1 0}$ & $\mathbf{2 0 1 1}$ & $\mathbf{2 0 1 2}$ & $\mathbf{2 0 1 3}$ & $\mathbf{2 0 1 4}$ & $\mathbf{2 0 1 5}$ & \multicolumn{1}{c|}{$\mathbf{2 0 1 6}$} \\
\hline Alternatifbank & $-17,43$ & $-12,95$ & $-11,02$ & $-9,27$ & $-4,94$ & 0,69 & 4,31 \\
\cline { 2 - 8 } Arap Türk Bankas1 & $-1,72$ & 7,51 & 25,30 & 10,01 & 17,87 & 15,24 & 18,04 \\
\cline { 2 - 8 } Burgan Bank & $-3,36$ & 8,94 & $-1,59$ & $-0,38$ & $-5,01$ & $-7,60$ & $-10,12$ \\
\cline { 2 - 8 } Citibank & 21,01 & 18,79 & 19,38 & 37,49 & 37,17 & 33,90 & 33,77 \\
\cline { 2 - 8 } Denizbank & $-5,47$ & $-2,36$ & $-1,16$ & $-4,89$ & $-1,52$ & 2,28 & 1,50 \\
\cline { 2 - 8 } Deutsche Bank & 46,85 & 32,60 & 39,91 & 30,35 & 32,61 & 26,04 & 38,01 \\
\cline { 2 - 8 } HSBC Bank & 7,22 & 9,12 & 4,52 & 14,45 & 12,17 & 6,42 & 5,90 \\
ICBC Turkey Bank & $-9,21$ & $-9,41$ & $-9,06$ & $-5,09$ & $-8,16$ & 8,93 & 5,77 \\
\cline { 2 - 8 } ING Bank & $-4,89$ & $-9,29$ & $-8,55$ & $-4,19$ & $-5,01$ & $-1,68$ & $-0,97$ \\
\cline { 2 - 7 } Turkland Bank & $-5,85$ & $-4,08$ & $-3,08$ & 0,07 & 1,44 & 4,96 & 10,72 \\
\cline { 2 - 6 } $\begin{array}{l}\text { Türiye Garanti Bankas1 } \\
\text { QNB Finansbank }\end{array}$ & 3,96 & 0,09 & 4,18 & $-1,21$ & $-3,23$ & $-2,67$ & $-3,55$ \\
\cline { 2 - 7 } & $-0,43$ & $-2,84$ & $-3,03$ & $-5,41$ & $-7,58$ & $-4,76$ & $-0,90$ \\
\hline
\end{tabular}

Genel olarak bankalar dağınık bir likidite performansı (Likit Aktifler/Toplam Aktifler, Likit Aktifler/Kısa Vadeli Yükümlülükler, TP Likit Aktifler/Toplam Aktifler) sergilemişlerdir. Burgan Bank, QNB Finansbank, ING Bank ve Türkiye Garanti Bankası 2016 y1lı itibariyle negatif bir likidite puanına sahip iken bu bankalar haricindeki bankaların pozitif ve iyi bir likidite performansına sahip oldukları gözlemlenmiştir. Likidite değeri düşük bankalarda kredilerin mevduattan daha fazla ve hızlı artması bu değerin düşüşüne sebep olabilecektir. Ayrıca bu bileşen içindeki oranlar sektör ortalamaları dikkate alındığında 2010 yılına göre düşüş göstermiştir. Ancak incelenen bankaların oranlarının genelde sektör ortalamasının üzerinde olduğu gözlemlenmiştir. 


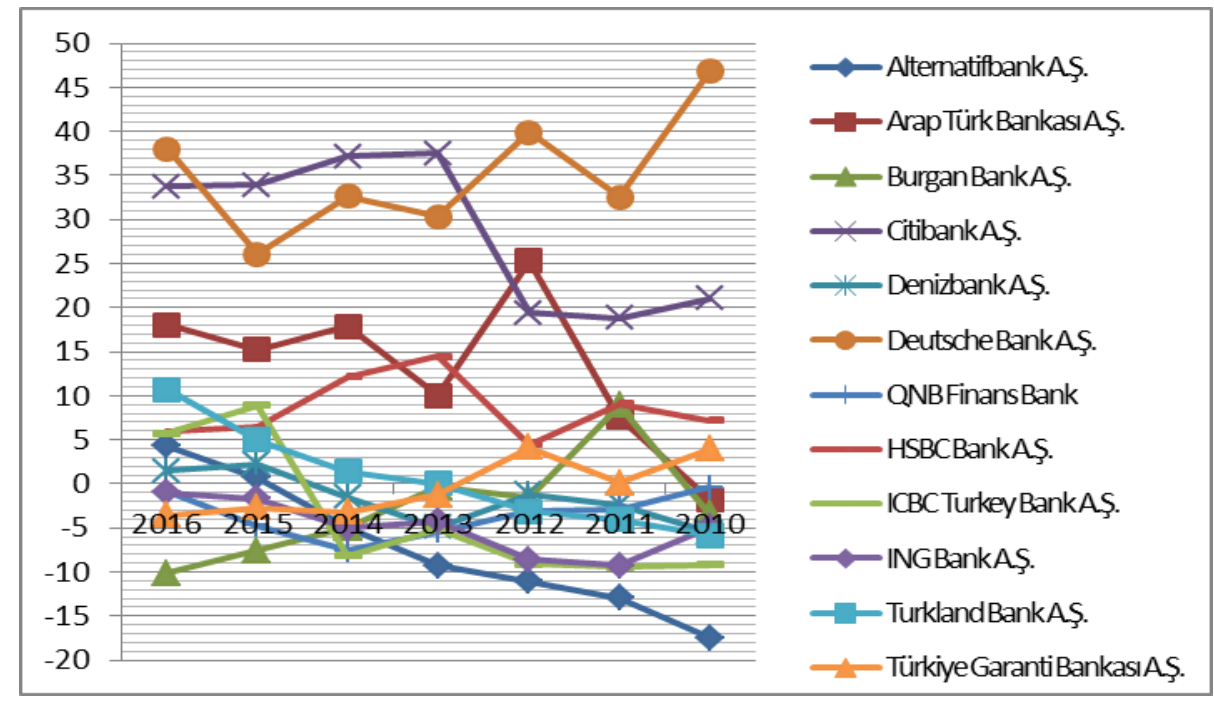

Şekil 5. Bankaların Likidite Durumu

2016 yılı için Burgan Bank, QNB Finansbank, ING Bank ve Türkiye Garanti Bankası'nın diğer bankaların altında bir likidite derecesine sahip olduğu ve beklenmedik piyasa koşullarında faaliyetlerinin devamında diğer bankaların gerisinde kaldıkları görülmektedir. Deutsche Bank, Citibank ve Arap Türk Bankası likidite açısından önde gelen ilk üç banka olmuşlardır. Alternatifbank 2014 yılına kadar sektörün gerisinde bir likidite yapısına sahip iken bu yıldan sonra iyi bir performans göstermiş hatta likidite derecesini en çok arttıran banka olmuştur.

\subsection{Piyasa Riskine Duyarlılık (S)}

$\mathrm{Bu}$ bileşen yoluyla bankanın faiz oranlarındaki, kurlardaki, mal fiyatlarındaki, hisse senedi fiyatlarındaki değişimlerden kaynaklanan piyasa riskine duyarlılı̆̆ 1 değerlendirilmektedir (Türker Kaya, 2001: 5). 5411 sayılı Bankacılık Kanunu'na göre bankalar risk yönetimi sistemi kapsamında, risk politikalarını BDDK tarafindan belirlenen esaslar çerçevesinde oluşturmak, uygulamak ve raporlamak zorundadır. Risk yönetimi faaliyetleri yönetim kuruluna bağlı olarak çalışacak risk yönetimi birimi ve personeli tarafindan yürütülmektedir.

Tablo 11. Riske Duyarlılık Değerleri

\begin{tabular}{l|r|r|r|r|r|r|r|}
\hline \multicolumn{1}{|c|}{ Banka } & $\mathbf{2 0 1 0}$ & $\mathbf{2 0 1 1}$ & $\mathbf{2 0 1 2}$ & $\mathbf{2 0 1 3}$ & $\mathbf{2 0 1 4}$ & $\mathbf{2 0 1 5}$ & $\mathbf{2 0 1 6}$ \\
\hline Alternatifbank & $-1,20$ & $-1,49$ & $-0,98$ & 0,56 & 2,59 & 0,08 & 4,64 \\
\cline { 2 - 8 } Arap Türk Bankası & 2,07 & 4,03 & 2,46 & 3,58 & 4,19 & 4,30 & 5,60 \\
\cline { 2 - 8 } Burgan Bank & 3,44 & 3,10 & 2,34 & $-1,69$ & 0,11 & 0,47 & 1,87 \\
\cline { 2 - 8 } Citibank & $-1,77$ & 1,06 & $-1,63$ & 2,78 & 2,60 & 0,63 & 1,36 \\
\cline { 2 - 8 } Denizbank & $-1,62$ & $-1,37$ & 0,56 & $-2,08$ & $-0,18$ & $-1,00$ & 1,23 \\
Deutsche Bank & $-7,03$ & 5,33 & 8,79 & 6,51 & 4,66 & 3,44 & 6,17 \\
\cline { 2 - 8 } HSBC Bank & $-1,27$ & $-2,01$ & $-3,04$ & $-1,66$ & $-3,28$ & $-2,86$ & 0,35 \\
ICBC Turkey Bank & 2,99 & 1,30 & 1,07 & 0,11 & 1,81 & $-0,65$ & 5,12 \\
\cline { 2 - 8 } ING Bank & 0,82 & $-0,22$ & 0,68 & $-0,16$ & $-0,63$ & $-3,51$ & $-1,11$ \\
\cline { 2 - 8 } Turkland Bank & 2,78 & 2,83 & 2,93 & 3,59 & 4,12 & 4,69 & 4,18 \\
\cline { 2 - 6 } Türe Garanti Bankas1 & 3,75 & 3,20 & 2,66 & 2,97 & 1,94 & 1,86 & 0,31 \\
\cline { 2 - 8 } QNB Finansbank & 1,13 & 0,04 & $-0,31$ & 1,16 & $-0,08$ & $-2,58$ & $-3,19$ \\
\hline
\end{tabular}


Bankaların riske duyarlılık (YP Likit Aktifler/YP Pasifler, Net Bilanço Pozisyonu/Özkaynaklar, Özel Karşılıklar Sonrası Net Faiz Geliri/Toplam Faaliyet Geliri, Faiz Geliri/Toplam Aktifler) puanları genel olarak yükselmiş olup, Deutsche Bank yine daha iyi ve yüksek bir performansa sahip olmuştur. Örneğin Türkiye'de kurulmuş yabancı sermayeli bankalar için bu bileşen içinde yer alan net bilanço pozisyonu / özkaynak oranı 2010 yılında 93 iken 2016 yılında -63'e yükselmiş olup, negatif değer özkaynakların kur riskini karşılamada yetersiz kaldığını ancak oranın yükselmesi kur riskine karşı bankaların dayanıklılıklarının arttığını göstermektedir.

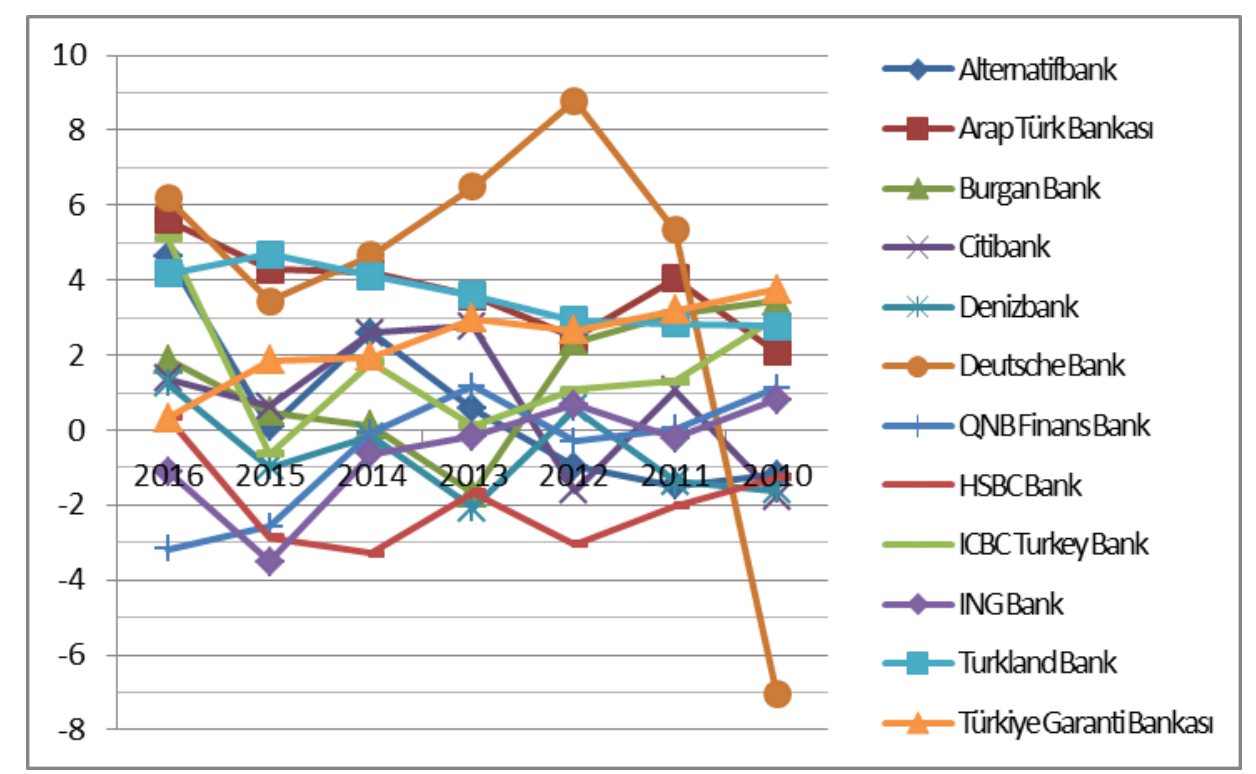

Şekil 6. Bankaların Piyasa Riskine Duyarlılığ1

Genel olarak bankaların piyasalarda meydana gelebilecek kırılganlıklara karş1 dayanıklı oldukları sonucuna ulaşılmıştır. İncelenen bankaların \% 75' inin riske duyarlılık derecelerini yükselttikleri Burgan Bank, QNB Finansbank, Türkiye Garanti Bankası ve ING Bank'ın puanlarının az da olsa düştüğü QNB Finansbank ve ING Bank'ın 2016 yılı için negatif değer alarak sektörün gerisinde kaldığg gözlemlenmiştir. Turkland Bank'ın puanını istikrarlı bir şekilde arttırdığ 1 , Deutsche Bank'ın ise büyük sıçramalarla skorunu arttırdığ sonucuna ulaşılmıştır.

Tablo 12. CAMELS Toplam Değerleri

\begin{tabular}{l|r|r|r|r|r|r|r|}
\hline \multicolumn{1}{|c|}{ Banka } & $\mathbf{2 0 1 0}$ & $\mathbf{2 0 1 1}$ & $\mathbf{2 0 1 2}$ & $\mathbf{2 0 1 3}$ & $\mathbf{2 0 1 4}$ & \multicolumn{1}{c|}{$\mathbf{2 0 1 5}$} & \multicolumn{1}{c|}{$\mathbf{2 0 1 6}$} \\
\hline Alternatifbank & $-25,73$ & $-28,00$ & $-18,22$ & $-3,30$ & 8,40 & $-12,40$ & $-10,69$ \\
\cline { 2 - 8 } Arap Türk Bankas1 & 47,00 & 35,72 & 53,75 & 61,04 & 72,78 & 45,90 & 30,35 \\
\cline { 2 - 8 } Burgan Bank & $-7,27$ & 12,79 & $-14,93$ & $-31,10$ & $-14,22$ & $-17,76$ & $-21,94$ \\
\cline { 2 - 8 } Citibank & 15,20 & $-6,89$ & 10,36 & 98,78 & 113,89 & 80,89 & 67,72 \\
\cline { 2 - 8 } Denizbank & $-3,56$ & 6,99 & 5,47 & $-4,29$ & $-1,53$ & $-1,51$ & 0,93 \\
\cline { 2 - 8 } Deutsche Bank & 3,67 & 142,64 & 395,77 & 57,26 & 347,55 & 192,49 & 134,34 \\
\cline { 2 - 8 } HSBC Bank & 3,65 & $-0,12$ & $-8,69$ & $-6,32$ & $-17,95$ & $-33,25$ & $-34,60$ \\
\cline { 2 - 8 } ICBC Turkey Bank & $-7,30$ & $-13,96$ & $-15,57$ & 10,44 & $-9,49$ & $-14,11$ & $-3,86$ \\
\cline { 2 - 8 } ING Bank & $-15,53$ & $-22,22$ & $-13,45$ & $-6,87$ & $-12,38$ & $-19,79$ & $-6,42$ \\
\cline { 2 - 3 } & $-15,73$ & $-11,31$ & $-14,78$ & 2,65 & 13,82 & $-3,85$ & $-0,58$ \\
\cline { 2 - 7 } Türkiye Garanti Bankas1 & 34,77 & 22,65 & 23,40 & 37,31 & 26,37 & 10,29 & 7,55 \\
\cline { 2 - 7 } QNB Finansbank & 14,11 & 4,63 & 1,49 & 10,89 & 7,44 & $-11,79$ & $-7,93$ \\
\hline
\end{tabular}


İncelenen yıllar itibariyle Türkiye'de kurulmuş Yabancı sermayeli bankaların CAMELS performans sonuçları (Sermaye Yeterliliği, Aktif Kalitesi, Yönetim Kalitesi, Kârlılık, Likidite ve Piyasa Riskine Duyarlılık) yukarıdaki tabloda görüldüğü gibidir. Deutsche Bank performansını muazzam bir şekilde arttırmış iken bu bankayı Citibank takip etmektedir. HSBC Bank ise pozitif performanstan negatif performans değerine sahip olup, incelenen y1llar itibariyle büyük bir düşüş göstermiştir.

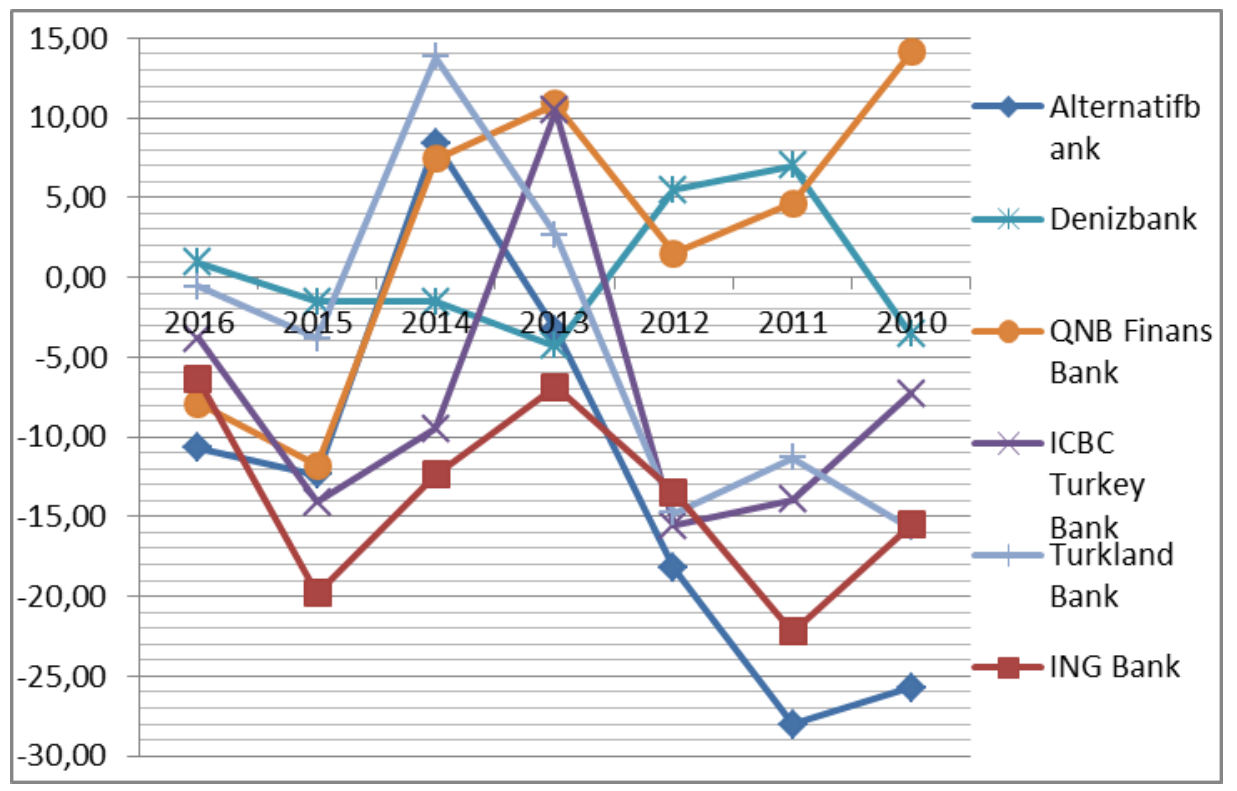

Şekil 7. CAMELS Genel Sonuçları

Alternatifbank A.Ş.: 2011 yılından sonra performans1 yükselerek 2014 y1lında negatif değerlerden pozitife dönüştürmeyi başarabilmiştir. Diğer y1llarda hep negatif bir değer almıştır. 2014 yılından itibaren performansında gerileme yaşanmış ancak 2016 yılında toparlanarak performansını az da olsa yükseltebilmiştir. Genel olarak incelenen yıllarda aktif yeterliliği, likidite ve riske duyarlılık açısından iyi bir performans göstererek CAMELS puanını yükseltmiştir.

Denizbank A.Ş.: 2010 ve 2011 dönemleri için yükselen trendde performans sergilemiş, 2012 yılında kırılganlık yaşayarak 2013 yılında negatif değere dönmüş ancak bu yıldan sonra performansını yükseltmeye başlamış ve 2016 yılında pozitif bir performans sahibi olmuştur. Genel olarak sermaye ve aktif yeterliliğinde pek bir değişim olmaz iken yönetim kalitesi ve kazançlarında az da olsa düşüş yaşanmıştır. Likidite açısından iyi bir performans göstermiştir.

QNB Finansbank A.Ş.: 2010-2012 dönemlerinde performansı düşüş trendine girmiş ancak 2013 ve 2014 yıllarında toparlanmayı başararak yüksek performans sergilemiştir. 2015 yılında negatif bir performans göstermiş ve 2016 yılından diğer bankalar gibi performansında artış gözlemlenmiş̧tir.

ICBC Turkey Bank A.Ş.: Banka 2010, 2011 ve 2012 yılları hariç aşırı derecede dalgalı bir yapıda performans göstermiştir. 2013 yılı hariç negatif değerlerde performans 
derecesine sahip iken 2016 yılında performans iyileşmesi görülmüştür. Analiz dönemlerinde likidite yeterliliği, riske duyarlılık ve aktif yeterliliği açısından performansını yükseltebilmiştir.

Turklandbank A.Ş.: Sermaye yeterliliği, likidite kalitesi ve riske duyarlılık açısından performans artışı gözlemlenirken aktif yeterliliği ve yönetim kalitesinde bir miktar düşüş yaşanmış olup, karlılığında da 2010 yılından itibaren bir miktar iyileşme görülmüş ancak 2015 ve 2016 dönemlerinde yeniden performans derecesi gerilemiştir. Genel olarak performansında iyileşme gözlemlenmektedir. 2013 ve 2014 yıllarında pozitif ve yüksek bir performans derecesine sahip olmuştur.

ING Bank A.Ş.: Analiz dönemlerinde negatif puanlı derecelere sahip olmuştur. Aktif yeterliliği ve riske duyarlılık derecelerinde gerileme yaşanır iken sermaye yeterliliği, karlılık, yönetim kalitesi ve likidite açısından performansını arttırabilmiştir. Genel olarak dalgalı bir performans derecesine sahip olsa da incelenen dönemlerde performansinda pek fazla bir değişiklik gösterememiştir.

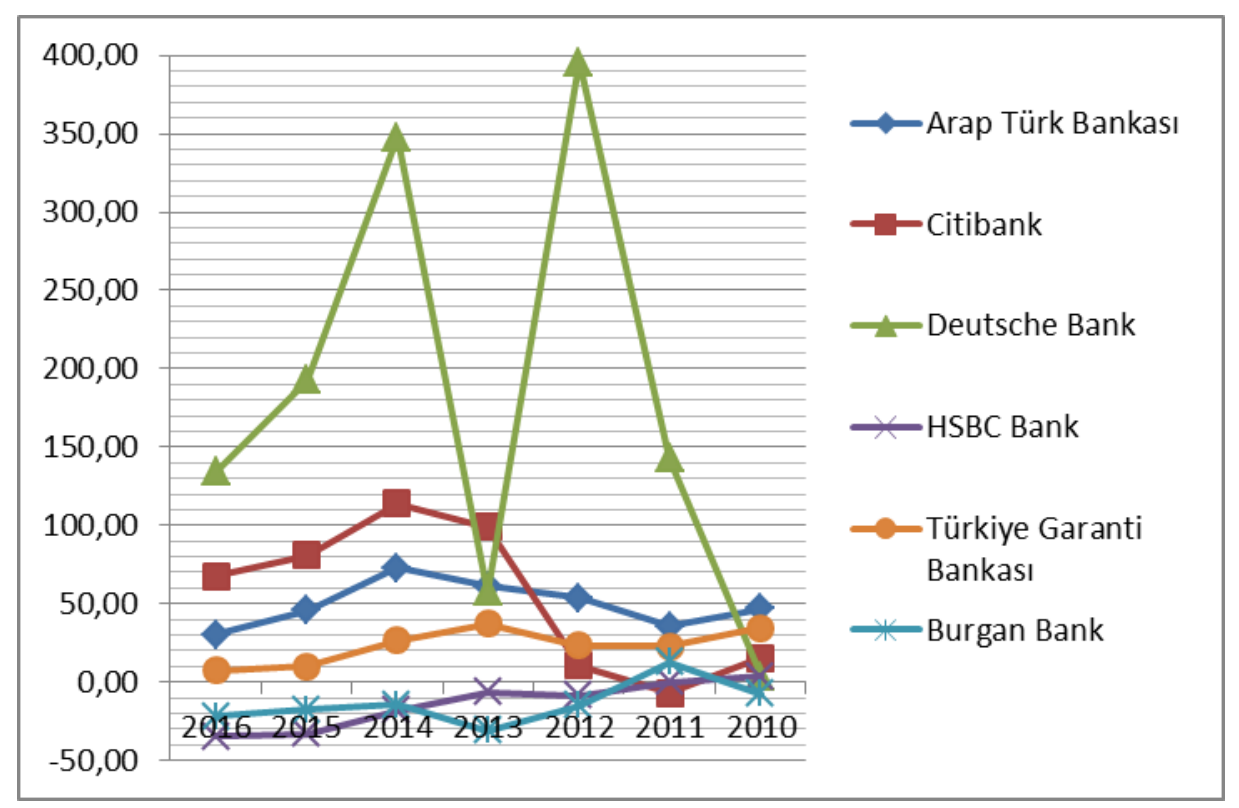

Şekil 8. CAMELS Genel Sonuçları (Devamı)

Arap Türk Bankası A.Ş.: İncelenen dönemlerde bileşenler içinde likidite durumu bakımından çok iyi performans göstermiştir. Riske duyarlılık açısından iyi bir konumda bulunmaktadır. 2010 yılından itibaren karlılığında artış yaşanmış, 2013 ve 2014 yıllarında en yüksek kârlılık performansına sahip olmuş ve 2014 yılından sonra kârlılığında düşüş yaşanmıştır. Genel olarak performansında fazla bir değişiklik olmasa da 2013 ve 2014 yıllarında yüksek bir performans göstermiş, sonraki yıllarda ise düşüş trendine girmiştir.

Citibank A.Ş.: 2011 y1lı bankanın performansı açısından kırılma dönemi olup, 2013 ve 2014 y1lında sermaye yeterliliği, yönetim kalitesi, karlılık, riske duyarlılık ve likidite yeterliliği konularında iyi bir ivme yakalayabilmiştir. CAMELS performansı2011 yılından sonra artış trende iken 2014 yılından sonra düşmeye başlamıştır. 
Deutsche Bank A.Ş.: 2010 yılından sonraki yıllarda pozitif ve yüksek seviyelerde skorla muazzam bir performans artışı görülmektedir. Her ne kadar sermaye yeterliliği ve likidite durumunda performans düşüşü görülse de, aktif yeterliliği, yönetim kalitesi, kârlılık, piyasa riskine olan duyarlılıktaki artışlar özellikle de yönetim kalitesindeki artış performans artışında önemli bir destek olmuştur. İncelenen dönemlerde diğer bankalardan ayrışarak yüksek performans göstermiştir.

HSBC Bank A.Ş.: Sermaye yeterliliği, aktif yeterliliği, yönetim kalitesi ve kârlılık konularında negatif değerlere sahip olduğu ve yıllar itibariyle performans düşüklüğü görülmektedir. Bu bileşenler doğrultusunda CAMELS puanı da incelenen yıllarda sürekli bir düşüş göstermiştir. İncelenen dönemlerde diğer bileşenlere göre likidite ve riske duyarlılık açısından iyi bir performans gösterdiği söylenebilir.

Türkiye Garanti Bankası A.Ş.: Toplam performans puanında sürekli dalgalanmalar yaşayarak düşüş gerçekleşmiştir. En büyük düşüş; yönetim kalitesi, karlılık, likidite yeterliliğinde gerçekleşmiş ancak 2013 yılından sonra CAMELS puanı düşüş trendine girmiştir.

Burgan Bank A.Ş.: İncelenen dönemler boyunca bileşenlerinde sürekli bir gerileme olduğu görülmektedir. Aktif ve likidite yeterliliği konularında en fazla düşüş gerçekleşmiştir. Sermaye yeterliliği ve yönetim kalitesi bakımından fazla bir değişim olmayıp, kârlılığını az da olsa iyileştirmeyi başarabilmiştir. Likidite yeterliliği bakımından da 2011 yılı hariç negatif değerlere sahip olup, performansında da sürekli düşüş yaşamıştır. 2013 yılından itibaren riske duyarlılık açısından toparlanmaya başlamıştır.

\section{Bankalar birey ve SONUÇ}

Kurumların finansal olarak desteklenmesine, tasarrufların ekonomiye kazandırılarak yatırıma dönüştürülmesine aracılık eden en önemli kurumlardır. $\mathrm{Bu}$ nedenle bankaların finansal yapılarında meydana gelen bozulmalar hem sektöre olan güveni azaltacak hem de genel ekonomi içinde pek çok yapısal sorunlara yol açacaktır. Dolayısıyla bankalarda ve bankacılık sektöründe ortaya çıkması muhtemel sorunların önceden tahmin edilerek bu doğrultuda pozisyon alınması banka hissedarları ve çalışanları, devlet, toplum ve ülke açısından önem arz etmektedir. Çalışmamızda dünyada pek çok otorite tarafindan genel kabul görmüş CAMELS analiz yöntemi kullanılarak Türkiye'de kurulmuş 12 yabancı sermayeli bankanın 2010-2016 yılları performansları derecelendirilmiştir. Citibank, Denizbank, ING Bank, Turkland Bank ve Türkiye Garanti Bankası'nın sermaye yeterliliklerinin arttığ gözlemlenmiştir. Denizbank, Deutsche Bank, ICBC Turkey Bank ve QNB Finansbank'ın aktif yeterliliklerinde artış olduğu; Citibank, Deutsche Bank ve ING Bank'ın yönetim kalitesinin yükseldiği; Burgan Bank, Citibank, Deutsche Bank, ING Bank ve Turkland Bank'ın kârlılıklarında artış gözlemlenmiştir. Alternatifbank, Arap Türk Bankası, Citibank, Denizbank, ICBC Turkey Bank, ING Bank ve Turkland Bank'1n likidite yeterliliklerinin yükseldiği; Alternatifbank, Arap Türk Bankası, Citibank, Denizbank, Deutsche Bank, HSBC Bank, ICBC Turkey Bank ve Turkland Bank'ın piyasa riskine duyarlılık skorlarının arttığ sonucuna ulaşılmıştır.

Genel olarak, bankaların çoğunluğunun sermaye yeterliliği, aktif yeterliliği, yönetim kalitesi ve kârlılık performansları düşerken; likidite ve riske duyarlılık performanslarının 
yükseldiği gözlemlenmiştir. Sermaye yeterliliğinde fazla bir değişiklik olmasa da bazı bankaların sektörün gerisinde kaldığ 1 tespit edilmiş̧ir. Elde edilen sonuçlar bileşenler bazında değerlendirildiğinde bazı olumsuzluklar görünse de bankaların yarısının analiz edilen yıllar itibariyle CAMELS performanslarını arttırdıkları tespit edilmiştir. Performansı en fazla artan ilk üç banka sırasıyla Deutsche Bank, Citibank ve Turkland Bank olmuştur. İncelenen dönemler ve bankalar içinde Deutsche Bank'ın puanlarının diğer bankalara nazaran çok büyük kırılganlıklar gösterdiği dikkatimizi çekmiş olup, bunun bir anomaliden mi yoksa finansal durumundaki ani değişikliklerden mi kaynaklandığı ayrıca araştırılması gereken bir konu olarak karşımıza çıkmaktadır. Bankalar finansal piyasalarda aktif bir rol oynayan kurumlar olmaları sebebiyle ülkenin ekonomik konjonktüründen çok kısa sürede etkilenmektedirler. Ayrıca bankalar da ülkenin ekonomisi üzerinde olumlu veya olumsuz derin etkiler bırakabilmektedirler. Dolayısıyla bankacılık sektörünün yapısal olarak güçlü olması ülkenin gelişiminde önemli bir rol oynayacaktır. Diğer taraftan analiz neticesinde elde edilen sonuçlar banka yöneticilerine ve hissedarlarına, yatırımcılara, kamu otoritelerine ve araştırmacılara referans olabilecektir. Ayrıca analizde kullanılan finansal oranların ağırlıkları subjektif olarak belirlendiğinden elde edilen sonuçların göreceli olduğu unutulmamalıdır.

\section{KAYNAKLAR}

Abdullayev, Mezahir (2013), "Türk Bankac1lı Sektöründe Dezenflasyon Sürecinde CAMELS Analizi”, Dumlupınar Üniversitesi Sosyal Bilimler Dergisi, Sayı 37, ss.97112.

Ahmedov, Turan - Memmedov, Elsever (2017), "Azerbaycan Bankacilık Sektöründe CAMELS Analizi: Yabanc1 Sermayeli 10 Banka", İktisadi İdari ve Siyasal Araştırmalar Dergisi, Cilt 2 Sayı 4, ss.97-109.

Altemur, Necati - Karaca, Süleyman Serdar - Güvemli, Batuhan (2018), "Türkiye'deki Yabancı Sermayeli Bankaların CAMELS Analizi ile Performanslarının Ölçülmesi”, Journal of International Management, Educational and Economics Perspective, Volume 6 Issue 1, ss.57-65.

Arıçelik, Gülçin (2010), Ticari Bankalarda Performans Ölçümü: CAMELS Analizine Dayalı bir İnceleme, Yayınlanmamış Tüksek lisans Tezi, Dokuz Eylül Üniversitesi Sosyal Bilimler Enstitüsü,

Ateşoğlu Coşkun, Sevda - Kargın, Sibel (2016), "Sınır Ötesi Birleşme ve Satın Almaların Bankaların Finansal Performansına Etkileri: Üç Banka Üzerine CAMELS Analizi”, Muhasebe ve Finansman Dergisi, Sayı 69, Ocak 2016, ss.41-60

Aytekin, Sinan - Sakarya, Şakir (2013), "BİST’teki Mevduat Bankalarının Finansal Performanslarının 2001 ve 2008 Finansal Krizleri Çerçevesinde CAMELS Derecelendirme Sistemi ile Değerlendirilmesi”, AİBÜ Sosyal Bilimler Enstitüsü Dergisi, Cilt 13 Say1 2,13: ss.25-58

BDDK (2018a), Türkiye'de Bankacılık Sistemi Seçilmiş Rasyolar 2006-2016, https://www.tbb.org.tr/tr/bankacilik/banka-ve-sektor-bilgileri/istatistiki-raporlar/59 $(31 / 05 / 2018)$ 
BDDK (2018b), BDDK tarafindan bankalara ilişkin herhangi bir derecelendirme yapılmakta midir? https://www.bddk.org.tr/websitesi/turkce/kurum _bilgileri/SSS/10482denetim3.pdf ( 24/06/2018 ) .

Çağıl, Gülcan - Mukhtarov, Shahriyar (2014), “Azerbaycan Ticari Bankacılık Sektörünün CAMELS Yöntemi ile Performans Analizi”, Marmara Üniversitesi Öneri Dergisi, Cilt 11, Say1 41, ss.77-94.

Çinko, Murat - Avcı, Emin (2008), "CAMELS Derecelendirme Sistemi ve Türk Ticari Bankacılık Sektöründe Başarısızlık Tahmin”, BDDK Bankacılık ve Finansal Piyasalar Dergisi, Cilt 2, Say1, 2, ss.25-48.

Federal Reserve (FED) (2018), About the FED, (https://www. federalreserve. gov/aboutthefed.htm) $(20 / 11 / 2018)$.

Federal Deposit Insurance Corporation (FDIC), Mission, Vision and Values, https://www.fdic.gov/about/strategic/strategic/mission.html (20/11/2018)

Gümüş, Fatih B. - Nalbantoğlu, Öner (2015), “Türk Bankacıllk Sektörünün CAMELS Analiz Yöntemiyle 2002-2013 Yilları Arasında Performans Analizi”, AKÜ İİBF Dergisi Cilt 17 Say1 2,ss. 83-106

Gündoğdu, Aysel (2017), Türkiye'de Mevduat Bankalarının CAMELS Analizi, Bankacılık ve Finansal Araştırmalar Dergisi, Cilt 4 Sayı 2, ss.26-43.

İşeri, Müge - Ulusan, Meltem (2007), Ülkemiz Bankacılık Sektöründe Yabancı Bankaların Yeri, Muhasebe ve Finansman Dergisi,Sayı 33, Ocak 2007, ss.31-138

Jaffar, Muhammad - Manarvi, Irfan (2011), "Performance Comparison of Islamic and Conventional Banks in Pakistan", Global Journal of Management and Business Research, Volume 11, Issue 1 Version 1.0, February, pp.61-66

Kavun, Sergii - Vorotintcev, Mihail (2016), "Credit Risk Assessment for Financial Institution Activity”, Journal of Finance and Economics, Volume 4 No 5, pp.142-150

Lopez, Jose A. (1999), Using CAMELS Ratigs to Monitor Bank Conditions, https://www.frbsf.org/economic-research/publications/economicletter/1999/june/using-camels-ratings-to-monitor-bank-conditions/ (20/11/2018) .

Nurazi, Ridwan - Evans, Michael (2005), "An Indonesian Study of the Use of CAMEL(S) Ratios as Predictors of Bank Failure", Journal of Economic and Social Policy, Volume 10 Issue 1, pp.1-23

Nimalathasan, B. (2008), A Comparative Study of Financial Performance of Banking Sector in Bangladesh - An Application of Camels Rating System, Annals of University of Bucharest, Economic and Administrative Series, No. 2, pp.141-152

Rao, Priya (2018), “A Reviev on CAMELS+(S): (S) Shariah Rating For Islamic Banks”, Research Journal of Economics and Business Studies, Volume 07, No 07, pp.68-73 
Roman, Angela - Şargu, Alina Camelia (2013), "Analysing the Financial Soundness of the Commercial Banks in Romania: An Approach Based on the CAMELS Framework", Procedia Economics and Finance, 6, pp.703-712

Sakarya, Şakir (2010), “Camels Derecelendirme Sistemine Göre İMKB'deki Yerli ve Yabancı Sermayeli Bankaların Karşılaştırmalı Analizi”, Akademik Araştırmalar ve Çalışmalar Dergisi, Prof. Dr. Alaeddin Yavaşça Özel Sayısı, Haziran, ss.7-21

Sarker, Abdul Awwal (2005), "Camels Rating System in the Context of Islamic Banking: A Proposed ' $\mathrm{S}$ ' for Shariah Framework', Journal of Islamic Economics and Finance 1 (1)

Türker Kaya, Yasemin (2001), Türk Bankacılık Sektöründe CAMELS Analizi, BDDK MSPD Çalışma Raporları: 2001/6

Türkiye Bankalar Birliği (TBB) (2005), Türkiye'de Yabancı Bankalar, Bankacılar Dergisi,https://www.tbb.org.tr/Dosyalar/Arastirma_ve_Raporlar/turkiyede_yabanci_ba nkalar.pdf $(14 / 11 / 2018)$

Türkiye Bankalar Birliği (TBB) (2018a), Türkiye'de Bankacılık Sistemi Banka, Çalışan ve Şube Bilgileri, Haziran 2018, https://www.tbb.org.tr/tr/banka-ve-sektorbilgileri/istatistiki-raporlar/Banka,_Calisan_ve_Sube_Bilgileri_/3709 (29/07/2018)

Türkiye Bankalar Birliği (TBB) (2018b), Banka Grupları Bazında Seçilmiş Bazı Bilgiler,https://www.tbb.org.tr/tr/bankacilik/banka-ve-sektor-bilgileri/bankabilgileri/tarihsel-bilgiler/68 (31/05/2018)

Türkiye Bankalar Birliği (TBB), (2018c), Türkiye'de Faaliyet Gösteren Bankalar https://www.tbb.org.tr/tr/bankacilik/banka-ve-sektor-bilgileri/banka-bilgileri/tarihselbilgiler/68 (31/05/2018)

Türkiye Bankalar Birliği (TBB) (2018d), Seçilmiş Rasyolar, https://www.tbb.org.tr/tr/bankacilik/banka-ve-sektor-bilgileri/istatistiki-raporlar/59 $(31 / 05 / 2018)$

Yurttadur, Mustafa - Bulut, Kemalettin (2015), “Türkiye'de Bankacıllk Sektörünün Finansal Yapısı ve Bu Yapının Müşteri Tercihine Etkis”, Girişimcilik ve Kalkınma Dergisi cilt 10, say1 2, ss.164-184

5411 sayılı Bankac1lık Kanunu, http://www.mevzuat.gov.tr/MevzuatMetin/1.5.5411.pdf (25/06/2018) 